\title{
Demografske promjene na hrvatskim otocima na početku 21. stoljeća
}

DOI: $10.11567 /$ met.29.2.3

UDK314.8(497.5)(210-7)“2001/2011”

Pregledni rad

Primljeno: 18.10.2013.

Prihvaćeno: 29.11.2013.

\section{Ivan Lajić}

Institut za migracije i narodnosti, Zagreb

\section{Roko Mišetić}

Hrvatsko katoličko sveučilište, Zagreb

\begin{abstract}
SAŽETAK
U velikom dijelu 20. stoljeća demografski razvoj hrvatskih otoka obilježava depopulacija. Ona počinje 1921., a po službenim statističkim pokazateljima završava u posljednjem desetljeću toga stoljeća. Uzrokovana je dugogodišnjim iseljavanjem s otokâ potaknutim gospodarskim (agrarna prenapučenost, industrijalizacija kopna, deagrarizacija, krize pojedinih poljoprivrednih djelatnosti, monokultura na pojedinim otocima itd.) i političkim uzrocima (političko iseljeništvo, talijanski optanti). Za formiranje ukupne depopulacije sve do šezdesetih godina presudna je emigracijska depopulacija, dok se nakon tog razdoblja njoj pridružuje i prirodna depopulacija, koja mnoge otočne zajednice dovodi do ekstremnoga depopulacijskog stanja - izumiranja. No od popisa stanovništva 1991. opće kretanje stanovništva hrvatskog otočja ima pozitivan predznak. Zaključak da je na otocima došlo do populacijske revitalizacije brzo je demantiran nizom činjenica. Budući da je od 1993. primijenjen zakon popularno nazvan »zakon o vikendicama«, brojni su se vlasnici kuća za odmor opredijelili za to mjesto kao lokaciju pretežnog mjesta stanovanja premda u njemu ne borave tijekom većeg dijela godine, stvarajući tako značajni kontingent »fiktivnog stanovništva«. Druga teza koja demantira da naši otoci proživljavaju demografski polet i revitalizaciju počiva na činjenici da su daleko najviše stope rasta broja stanovnika zabilježene na premoštenim otocima. Smatramo da ti otoci (koje ujedno karakterizira najveći udio kuća za odmor u ukupnom broju svih objekata) ne dijele sudbinu otočnosti (inzularnosti) kao ostali »pravi otoci« jer su čvrstom vezom povezani s kopnom i ustvari više nisu izolirani. Ako isključimo kretanje broja stanovnika te skupine otoka iz kretanja ukupnog stanovništva cjelokupnog otočja, možemo ustvrditi da je u proteklom razdoblju i prihvaćajući »fiktivno stanovništvo « kao statistički realitet, broj stanovnika naših otoka stagnirao.
\end{abstract}

KLJUČNE RIJEČI: hrvatski otoci, depopulacija, dobni sastav stanovništva, vitalnost, »fiktivno stanovništvo« 


\section{UVOD}

Namjera ovog rada nije preciznije obrazlaganje što je uzrokom dugoga depopulacijskog razdoblja koje je pratilo naše otoke od 1921. ${ }^{1}$ do 1991., međutim ipak valja naglasiti da je ta nepovoljna demografska pojava velikim dijelom bila uzrokovana zaostajanjem otočnoga gospodarskog razvoja u usporedbi s kopnenim dijelom, gospodarskim krizama kroz koje su prolazile glavne gospodarske grane otočnog sustava (poljoprivreda, brodogradnja, pomorstvo, koraljarstvo, spužvarstvo itd.), političkim zbivanjima, ratnim gubicima, zanemarivanjem otočnog prostora i stanovništva u gospodarskim strategijama i društveno-gospodarskim planovima. Destimulirajući procesi koji su utjecali na demografski razvoj prvo utječu na pojačanu otočnu emigraciju, koja određuje mehaničku depopulaciju te svojim intenzitetom nadvladava otočni prirodni prirast, koji je unatoč eroziji najmlađe otočne populacije i ubrzanom starenju bio pozitivan sve do sedamdesetih godina prošlog stoljeća. Nakon toga emigracijsku depopulaciju potencira i prirodna depopulacija, što je upućivalo na još pesimističnije demografske perspektive otočnoga demografskog razvoja. ${ }^{2} U$ tome sumornom ozračju sve demografske procjene, prognoze i projekcije nezaobilazno su upućivale na daljnje zaoštravanje negativnih razvojnih, a u tom segmentu naročito demografskih procesa. Ubrzano starenje stanovništva, smanjenje rađanja uz stalni porast broja umrlih i gospodarsko zaostajanje otoka bili su osnovna pretpostavka prirodnoga i mehaničkoga kretanja stanovništva. Uz te pojave sukladno su tekle i snažne društveno-političke promjene, među kojima je najznačajnija bila osamostaljenje hrvatske države i njezin izlazak iz sastava Jugoslavije.

U tom ozračju i nagovještaju dramatičnih ratnih zbivanja proveden je popis stanovništva 1991. Tada se realno očekivao negativniji nastavak trenda općega kretanja broja stanovnika naših otoka, međutim rezultati popisa neočekivano su pokazali da je višedesetljetno depopulacijsko kretanje na našim otocima zaustavljeno. Ta demostatistička činjenica naše je demografe, nisologe i ostale poznavatelje otočnih zbivanja zatekla te su objektivno

Tada su naši otoci brojili 174.703 stanovnika (Smoljanović, Smoljanović i Nejašmić, 1999: 429).

2 Demografska otočna istraživanja pokazala su da je prirodna depopulacija gotovo istovremeno zahvatila dalmatinske i kvarnerske otoke. Lajić za dalmatinske otoke konstatira: »Sve do 1968. godine stanovništvo Dalmatinskih otoka karakterizira pozitivni prirodni prirast (...) da bi kontinuirani godišnji pad 1968. [misli se na natalitet] doveo do stope denataliteta koja je iznosila 1\%o « (1992: 171). Za prirodno kretanje na kvarnerskim otocima Lajić konstatira da je razdoblje od 1961. do 1971. "prvo međupopisno razdoblje kada je na otočju više stanovnika umrlo (4234) negoli što je rođeno (3914)« (2006: 212). 
sumnjali u njezinu vjerodostojnost. Stoga prvi put u svoje rasprave uključuju termin »fiktivno stanovništvo« ili »stanovništvo na papiru«. Autori knjige Stanovništvo hrvatskih otoka to su iznimno povećanje otočnog stanovništva pripisali boljem popisivanju inozemnog stanovništva te istaknuli: »Popisi iz 1981. i 1991. obuhvaćali su po istoj metodologiji osobe na privremenom radu u inozemstvu i članove obitelji koji s njima borave. Međutim, popis iz 1991. godine iskazao je osjetno veći broj osoba na privremenom radu u inozemstvu (10.342 osobe) nego popis iz 1981. godine (bilo je 4055 osoba). Na razini pojedinih naselja i otoka razlike su još veće (npr. otok Olib 1981. godine imao je 3 osobe na privremenom radu u inozemstvu, a 1991. čak 571 osobu). Budući da u tome razdoblju nije došlo do enormne vanjske migracije (naprotiv, iseljavanje je slabije nego ranijih desetljeća), očito se radi o boljem popisnom obuhvatu 'inozemaca' (dijelom je broj stanovnika povećan i prijelazom vikendaša u stalne stanovnike). Prema tome, određeni porast broja stanovnika uglavnom zamagljuje stvarno stanje i predstavlja demografsku revitalizaciju 'na papiru' « (Smoljanović, Smoljanović i Nejašmić, 1999: 428).

Slični razlozi povećanja broja stanovnika dani su nekoliko godina prije u Nacionalnom programu razvitka otoka. No tu Lajić (1997: 17) ističe veću želju inozemaca da se iz domoljubnih razloga (uključujući i iseljeništvo, a ne samo one na privremenom radu i pridružene članove obitelji) registriraju kao stalno hrvatsko, odnosno otočno stanovništvo. Osim toga porastu broja otočne populacije 1991. pridonijeli su i vikendaši koji su se na otoke prijavljivali kao stalno stanovništvo. Premda je zakon o oporezivanju kuća za odmor donesen nakon popisa stanovništva (1993.), njegov je prijedlog već u vrijeme popisa problematiziran kroz medije i javne institucije, pa je i on bio djelomičnim povodom "prelaska« vikendaša (uglavnom starije životne dobi) u stalno otočno stanovništvo. Dok su 1991. glavninu »fiktivne otočne populacije« činile osobe na radu u inozemstvu i iseljenička populacija, u popisima 2001. i 2011. u toj kategoriji prevladavaju vlasnici kuća za odmor. I unutar te kategorije možemo provesti razdiobu. U ranijim popisima stanovništva popisani vlasnici kuća za odmor uglavnom su došljaci iz kontinentalnih dijelova Hrvatske koji su kupivši gradilišta izgradili kuće za odmor. Na temelju brojnih terenskih istraživanja Instituta za migracije i narodnosti iz Zagreba na pojedinim otočnim skupinama (šibenski otoci 2001. i 2010.; zadarski otoci 2004.; kvarnerski otoci 2005.) ${ }^{3}$ uočeno je da se u novije

3 Broj »fiktivnog stanovništva« u tijesnoj je korelaciji s brojem i udjelom kuća za odmor. Okvirna je ocjena, temeljena na grubim aproksimacijama dobivenima na otočnim terenskim istraživanjima, da je udio »fiktivnog stanovništva " na kvarnerskim, sjevernodalmatinskim i srednjodalmatinskim otocima oko petnaest posto ukupnog stanovništva, dok je na južnodalmatinskim otocima znatno manji. 
vrijeme kao uobičajeno otočno stanovništvo prijavljuje populacija otočnog podrijetla koja živi u priobalnim gradovima, a naslijedila je obiteljske kuće na otocima. U vremenu kada se stambena politika vodila dodjelom stanova, poduzeća su svome zaposleniku otočaninu koji je dotad bio cirkulant dodjeljivala stanove u priobalnome mjestu rada. Svojim umirovljenjem (a takvih je većina) oni zapravo ostvaruju dvojno boravište, ali se zbog potencijalnih beneficija koje im pruža otočno prebivalište (posebice brodske subvencionirane karte, naročito nakon usvajanja Zakona o otocima 1999.) prijavljuju kao stalno otočno stanovništvo. Brojni su posredni pokazatelji (prije svega registriranje u primarnoj zdravstvenoj zaštiti) da su oni i nadalje višestruko vezani uz naselje višeg standarda života, a to je u pravilu priobalni centar. Osim što umjetno povećava broj ukupnog stanovništva naših otoka (a s druge strane smanjuje broj stanovnika naselja u kojima pretežno živi), »fiktivno stanovništvo« bitno iskrivljuje demografske pokazatelje (stope nataliteta i mortaliteta), a naročito koeficijente dobnih ovisnosti jer se kao stalno otočno stanovništvo većinom prijavljuje roditeljska, pa i praroditeljska generacija. Ta kategorija stanovništva posebno iskrivljuje stvarnu sliku o samačkim domaćinstvima na otocima. Stoga je cilj ovog rada svojevrsno razotkrivanje privida o zaustavljanju otočne depopulacije na koji nas upućuju statistički podatci o porastu broja otočnog stanovništva u posljednjemu međupopisnom razdoblju te pokušaj utvrđivanja činjenica da bi se odgovorilo na pitanje: ponestaje li životne snage na hrvatskim otocima?

\section{METODOLOŠKE NAZNAKE}

Nijedno demografsko proučavanje naših otoka ne smije zanemariti barem tri osnovne skupine metodoloških problema. Prvu čine metodološki problemi vezani uz različitu popisnu metodologiju dvaju posljednjih popisa stanovništva te njihovu usporedivost/neusporedivost s prethodnim popisima. U tu problematiku uvrštavamo i probleme vezane uz povećanje broja stanovnika koje potencira »fiktivno otočno stanovništvo«. Drugu značajnu skupinu predstavlja problematika obuhvata otočnih naselja, otočno-obalnih naselja $i$ definiranje otočnih skupina. Treća skupina metodoloških problema nije isključivo otočna problematika, već se odnosi i na ostale male populacije, a to je općeniti problem statističkog prikazivanja malih populacija, čije je obilježje da male apsolutne promjene izazivaju enormno visoke relativne pokazatelje.

U popisima stanovništva 2001. i 2011. prevladava princip prisutnosti popisanih osoba u naselju popisa (de facto). Stariji su se popisi (oni prije 2001.) 
temeljili na principu prebivanja stanovništva u naselju popisa (de iure), odnosno osobe su popisane kao stanovnici naselja popisa neovisno o tome koliko u njemu borave. Iz te činjenice proizlazi da su rezultati popisa stanovništva 2001. i 2011. u visokoj razini međusobno usporedivi, međutim usporedivost tih popisa s onima iz druge polovine 20. stoljeća vrlo je teška i podliježe brojnim metodološkim spekulacijama. No »iako se podaci obaju popisa, 2001. i 2011., temelje na konceptu 'uobičajenog mjesta stanovanja', oni nisu neposredno usporedivi. To je tako najprije zbog namjere odsutnosti/prisutnosti koja se nije prikupljala u Popisu 2001., a potom i stoga što je Popis 2001. u ukupan broj stanovnika uključivao i osobe odsutne godinu i dulje koje su se u mjesto stalnog stanovanja vraćale sezonski i mjesečno (te se osobe u Popisu 2011. ne uključuju u ukupan broj stanovnika). « ${ }^{4}$ Kako bi se što više ublažile metodološke nekorektnosti, za popisni izvor ukupnog broja otočnog stanovništva 2001. i 2011. odabran je onaj koji se temelji na dobnoj strukturi stanovništva hrvatskih otoka, dok su metodološke nekorektnosti zanemarene jer ne utječu značajno na rezultate demografskih analiza u radu.

Premda to nije demografsko pitanje, u našoj nisologiji vrlo se često mijenja broj hrvatskih otoka. Aktualno se ističe broj od 1246 otoka (Duplančić, Ujević i Čala, 2004: 10), dok ih je do te brojidbe bilo »tek « 1185 (dakako, u oba je slučaja riječ o ukupnom broju otoka, otočića, grebena i hridi). Posebno je demografsko pitanje broj naseljenih hrvatskih otoka. Uobičajeno je da se većina rezultata popisa stanovništva iskazuje do razine naselja (mjerodavan je Imenik naselja Republike Hrvatske aktualan u vrijeme popisa). To stvara određene probleme u definiranju broja naseljenih otoka jer u Imeniku možemo pronaći samostalna svjetioničarska naselja koja broje samo jednog ili nekoliko stanovnika (npr. Palagruža), a ne bilježe se naseljeni otoci na kojima su administrativni dijelovi drugih naselja (npr. Košljun kao dio naselja Krk).

Veći su metodološki problem naselja čiji se teritorijalni obuhvat nalazi dijelom na otoku, a dijelom na kopnu (naselja Tisno i Trogir). U ovom će se radu otočno-obalno naselje Tisno, koje u svom sastavu ima kontinentalne dijelove naselja Gomilicu i Jazine, smatrati sastavnim dijelom otoka Murtera. Za razliku od Tisnog naselje Trogir, čiji se znatni dijelovi grada prostiru i na otoku Čiovu, neće se smatrati njegovim dijelom.

Popis stanovništva, kućanstava i stanova 2011. godine: metodološka objašnjenja, http://www.dzs. $\mathrm{hr} / \mathrm{Hrv} /$ censuses/census2011/results/censusmetod.htm. 
Najčešća geografska razdioba hrvatskih otoka na velike otočne skupine odnosi se na kvarnerske ${ }^{5}$ i dalmatinske otoke. Moguća je i geografska podjela na sjevernohrvatske, srednjohrvatske i južnohrvatske otoke, međutim brojni povijesni, gospodarski, aglomerativni, demografski i ostali čimbenici utjecali su na široku i učestalu navedenu dvojnu podjelu hrvatskoga otočnog prostora. Dalmatinske otoke možemo dijeliti na sjevernodalmatinske ${ }^{6}$, srednjodalmatinske ${ }^{7}$, i južnodalmatinske ${ }^{8}$ otoke, odnosno otočne skupine. Osim geografske razdiobe $\mathrm{u}$ ovom će se radu analizirati i otočne skupine izdvojene prema njihovoj vezi sa susjednim kopnom (premošteni i nepremošteni otoci). Skupini premoštenih otoka pripadaju Krk, Pag, Vir, Murter i Čiovo. Nadalje, posebno će biti izdvojena i analizirana skupina malih hrvatskih otoka. Jedna od značajnijih dilema demografskog istraživanja naših otoka njihova je podjela ovisno o demografskoj veličini. Nedvojbeno svi naši otoci, pa i oni s najbrojnijim stanovništvom, svrstavaju se u kategoriju malih populacija. No zbog preciznije raščlambe naše otoke najčešće dijelimo po dvojnom kriteriju, a to je njihova površina i broj stanovnika. Ako definiramo i nabrojimo male naseljene otoke, svi ostali pripadaju skupini većih hrvatskih otoka. Od brojnih definicija »malih otoka « praktično je za određenje tih otoka prihvatiti definiciju da su mali otoci »...poglavito oni naseljeni koji imaju 1-3 naselja, bez obzira na površinu i broj stanovnika, i koji nisu mostom povezani s kopnom « (Magaš, 2008: 20-21). Premda se ta definicija čini vrlo fleksibilnom, rabeći taj pristup prilikom istraživanja naših otoka, lako se dolazi do uvjerenja da je to praktična i vjerodostojna definicija za naše otočje. Naime ona vjerno obuhvaća, govorimo li poglavito o naseljenim otocima, one otoke koje i po drugim kriterijima vrlo lako svrstavamo u tu otočnu skupinu. Tako u skupinu malih otoka ulaze: Ilovik, Male Srakane, Vele Srakane, Susak, Unije, Silba, Olib, Premuda, Ist. Molat, Zverinac, Iž, Rava, Sestrunj, Rivanj, Ošljak, Vrgada, Prvić, Zlarin, Kaprije, Žirje, Krapanj, Kornati, Drvenik veli, Drvenik mali, Biševo, Sveti Andrija, Šipan, Lopud i Koločep.

Skupini kvarnerskih otoka pripadaju naseljeni otoci: Krk, Cres, Lošinj, Rab, Unije, Vele Srakane, Male Srakane, Susak i Ilovik.

6 Skupini sjevernodalmatinskih otoka pripadaju naseljeni otoci: Pag, Vir, Olib, Silba, Premuda, Ist, Molat, Sestrunj, Rivanj, Zverinac, Ošljak, Ugljan, Pašman, Iž, Rava, Dugi otok i Vrgada.

7 Skupini srednjodalmatinskih otoka pripadaju naseljeni otoci: Murter, Kornati, Prvić, Zlarin, Krapanj, Kaprije, Žirje, Drvenik mali, Drvenik veli, Čiovo, Šolta, Brač, Hvar, Vis, Biševo i Sveti Andrija.

8 Skupini južnodalmatinskih otoka pripadaju naseljeni otoci: Korčula, Lastovo, Mljet, Šipan, Lopud, Sušac i Koločep. 


\section{DEMOGRAFSKA POZICIJA OTOKA U UKUPNOM BROJU STANOVNIKA HRVATSKE}

Prostorno hrvatski otoci, kako površinom tako i morem koje ih okružuje, daleko više participiraju u površini pripadajuće matice zemlje nego što sudjeluju brojem stanovnika u ukupnom stanovništvu Hrvatske. Ta je situacija predvidljiva stoga što je tek mali broj naših otoka naseljen, a rijetki su oni koji imaju relativnu gustoću naseljenosti veću nego Republika Hrvatska. Ako toj računici pridodamo i pripadajući akvatorij, slaba naseljenost još se više potencira. Povijesno promatrano, otoci su kroz različite etape imali svekolike demografske uspone i padove. Društveno-gospodarski razvoj u čvrstoj je i tijesnoj korelaciji s demografskim razvojem, što zorno dokazuje i primjer hrvatskih otoka. Ovisno o povijesnim situacijama i ulozi otoka, koja je, istini za volju, najčešće bila marginalizirana, pulsiralo je kretanje njihova stanovništva. Cilj ovog rada nije definiranje određene faze povijesnoga demografskog otočnog razvoja, ali, zasigurno, otoci su u antičko doba imali daleko značajnije mjesto u povijesnim zbivanjima nego susjedno kopno. To možemo reći i za srednji vijek, a vjerojatno i za predindustrijsko doba.

Popisom stanovništva Hrvatske 2011. utvrđen je broj od 124.955 otočana kao stalnih stanovnika. Tim popisom istu kategoriju stanovništva Hrvatske činilo je 4.284.889 stanovnika, iz čega proizlazi da je udio otočnog stanovništva u stanovništvu Hrvatske bio 2,9\%. U usporedbi s prethodna tri popisa stanovništva (1981., 1991. i 2001.) došlo je do relativnog povećanja otočnog udjela. Kako se 2011. smanjio broj stanovnika Hrvatske u odnosu na prethodni popis, a na otocima je istovremeno zabilježen porast broja stanovnika, rezultat je porast njegova udjela u ukupnome hrvatskom stanovništvu. Godine 1981. otočno stanovništvo činilo je $2,5 \%$ cjelokupne hrvatske populacije u zemlji, što se nije bitno promijenilo ni prilikom sljedećeg popisa stanovništva 1991. (2,5\%). Godine 2001. ono čini 2,8\% ukupne hrvatske populacije.

Administrativno, otoke teritorijalno obuhvaća sedam županija, s time da se u šest nalaze naseljeni otoci. Istarska županija obuhvaća zapadnoistarski otočni niz, međutim na njemu ne nalazimo naseljena mjesta. U Primorskogoranskoj županiji nalaze se svi kvarnerski otoci. U Ličko-senjskoj županiji nalazi se samo sjeverni dio otoka Paga. Najbrojnije otočje ima Zadarska županija. Sljedeće je po brojnosti otočno područje koje obuhvaća Šibenskakninska, potom Splitsko-dalmatinska, i najjužnije, Dubrovačko-neretvanska županija. 
Tablica 1. Otočno stanovništvo u stanovništvu pripadajućih županija 2011.

Table 1. Island population in the population of respective counties, 2011

\begin{tabular}{|c|c|c|c|}
\hline \multirow{2}{*}{ Županija } & \multicolumn{2}{|c|}{ Broj stanovnika } & \multirow{2}{*}{$\begin{array}{l}\text { Udio otočnoga } \\
\text { u ukupnom } \\
\text { stanovništvu (\%) }\end{array}$} \\
\hline & ukupno & otoci & \\
\hline Primorsko-goranska & 296.195 & 39.706 & 13,41 \\
\hline Ličko-senjska & 50.927 & 3663 & 7,19 \\
\hline Zadarska & 170.017 & 20.952 & 12,32 \\
\hline Šibensko-kninska & 109.375 & 6063 & 5,54 \\
\hline Splitsko-dalmatinska & 454.798 & 36.338 & 7,99 \\
\hline Dubrovačko-neretvanska & 122.568 & 18.233 & 14,88 \\
\hline $\begin{array}{l}\text { Ukupno Republika } \\
\text { Hrvatska }\end{array}$ & 4.284 .889 & 124.955 & 2,92 \\
\hline
\end{tabular}

Izvor: Popis stanovništva, kućanstva $i$ stanova 2011., Stanovništvo prema starosti $i$ spolu po naseljima, Državni zavod za statistiku, Zagreb, 2011., http://www.dzs.hr/Hro/censuses/ census2011/results/htm/H01_01_01/H01_01_01.html.

Analiza udjela otočne populacije u ukupnom broju stanovnika županija pokazuje da su u vrijeme popisa 2011. Dubrovačko-neretvanska, Primorsko-goranska i Zadarska županija s udjelima iznad deset posto bile »otočnije« od Splitsko-dalmatinske, Ličko-senjske i Šibensko-kninske županije, u kojima je manje od desetine stanovništva živjelo na pripadajućim otocima (tablica 1).

\section{KRETANJE BROJA STANOVNIKA HRVATSKIH OTOKA OD 2001. DO 2011.}

Ukupni broj stanovnika hrvatskih otoka zabilježen popisom 2001. iznosio je $122.418^{9}$, a popisom 2011. godine $124.955^{10}$ stanovnika, što znači da je u deset godina došlo do povećanja statističkog broja od 2535 otočana i da je relativno povećanje bilo 2,1\%. Može se konstatirati da je i u tome među-

9 Popis stanovništva, kućanstava i stanova 2001., Stanovništvo prema spolu i starosti, po naseljima, Državni zavod za statistiku, Zagreb, 2001., http://www.dzs.hr/Hrv/censuses/Census2001/ Popis/H01_01_01/H01_01_01.html.

10 Popis stanovništva, kućanstava i stanova 2011., Stanovništvo prema starosti i spolu po naseljima, Državni zavod za statistiku, Zagreb, 2011., http://www.dzs.hr/Hrv/censuses/census2011/ results/htm/H01_01_01/H01_01_01.html. 
popisnom razdoblju predznak ukupnoga kretanja stanovništva kvarnerske i dalmatinske otočne skupine pozitivan, što je nastavak statistički povoljnih tendencija općega kretanja stanovništva posljednjeg desetljeća 20. stoljeća. Također se može ustvrditi da se stope porasta broja stanovnika u odnosu na to razdoblje smanjuju, i to nešto blaže kod kvarnerskoga otočnog stanovništva, gdje je međupopisni porast od 1991. do 2001. bio 3,7\%, dok je kod dalmatinske otočne populacije taj porast iznosio 4,2\%. Od 48 službeno naseljenih otoka 2001., nakon jednog desetljeća na Svetom Andriji više nema stalnih stanovnika. U tom razdoblju sedamnaest otoka bilježi porast broja stanovnika, dva imaju isti broj stanovnika, dok preostali otoci, a oni su prevladavajući u ukupnome otočnom broju, depopuliraju.

Premda kvarnerska otočna populacija bilježi veći relativni porast u usporedbi s dalmatinskom otočnom populacijom, na kvarnerskim otocima samo jedan otok ima porast broja stanovnika. To je premošteni otok Krk, kod kojeg je evidentiran porast više nego trostruko veći od depopulacije ostalih triju velikih kvarnerskih otoka (tablica 2).

Tablica 2. Kretanje broja stanovnika kvarnerskih otoka od 2001. do 2011. Table 2. Population trends on the Kvarner islands, 2001-2011

\begin{tabular}{|c|c|c|c|c|}
\hline \multirow{2}{*}{$\begin{array}{l}\text { Otok/otočna } \\
\text { skupina }\end{array}$} & \multicolumn{2}{|c|}{ Broj stanovnika } & \multirow{2}{*}{$\begin{array}{l}\text { Apsolutna } \\
\text { razlika (2011. } \\
\text { - 2001.) }\end{array}$} & \multirow{2}{*}{$\begin{array}{c}\text { Indeks } \\
\text { popisne } \\
\text { promjene }\end{array}$} \\
\hline & 2001. & 2011. & & \\
\hline Krk & 17.860 & 19.383 & 1523 & 108,5 \\
\hline Cres & 3184 & 3079 & -105 & 96,7 \\
\hline Lošinj & 7771 & 7587 & -184 & 97,6 \\
\hline Rab & 9480 & 9328 & -152 & 98,4 \\
\hline Unije & 90 & 88 & -2 & 97,8 \\
\hline Vele Srakane & 8 & 3 & -5 & 37,5 \\
\hline Male Srakane & 2 & 2 & 0 & 100,0 \\
\hline Susak & 188 & 151 & -37 & 80,3 \\
\hline Ilovik & 104 & 85 & -19 & 81,7 \\
\hline Kvarnerski otoci & 38.687 & 39.706 & 1019 & 102,6 \\
\hline Hrvatski otoci & 122.418 & 124.955 & 2537 & 102,1 \\
\hline
\end{tabular}

Izvor: Popis stanovništva, kućanstava i stanova 2001., Stanovništvo prema spolu $i$ starosti, po naseljima, Državni zavod za statistiku, Zagreb, 2001., http://www.dzs.hr/Hro/censuses/ Census2001/Popis/H01_01_01/H01_01_01.html; Popis stanovništva, kućanstava i stanova 2011., Stanovništvo prema starosti i spolu po naseljima, Državni zavod za statistiku, Zagreb, 2011., http://www.dzs.hr/Hrv/censuses/census2011/results/htm/H01_01_01/H01_01_01.html. 
Tablica 3. Kretanje broja stanovnika sjevernodalmatinskih otoka od 2001. do 2011.

Table 3. Population trends on Northern Dalmatian islands, 2001-2011

\begin{tabular}{|c|c|c|c|c|}
\hline \multirow{2}{*}{ Otok/otočna skupina } & \multicolumn{2}{|c|}{ Broj stanovnika } & \multirow{2}{*}{$\begin{array}{l}\text { Apsolutna } \\
\text { razlika } \\
\text { (2011. - } \\
\text { 2001.) }\end{array}$} & \multirow{2}{*}{$\begin{array}{c}\text { Indeks } \\
\text { popisne } \\
\text { promjene }\end{array}$} \\
\hline & 2001. & 2011. & & \\
\hline Pag & 8398 & 9059 & 661 & 107,9 \\
\hline Vir & 1608 & 3000 & 1392 & 186,6 \\
\hline Olib & 147 & 140 & -7 & 95,2 \\
\hline Silba & 265 & 292 & 27 & 110,2 \\
\hline Premuda & 58 & 64 & 6 & 110,3 \\
\hline Ist & 202 & 182 & -20 & 90,1 \\
\hline Molat & 207 & 197 & -10 & 95,2 \\
\hline Sestrunj & 48 & 48 & 0 & 100,0 \\
\hline Rivanj & 22 & 31 & 9 & 140,9 \\
\hline Zverinac & 48 & 43 & -5 & 89,6 \\
\hline Ošljak & 18 & 29 & 11 & 161,1 \\
\hline Ugljan & 6164 & 6049 & -115 & 98,1 \\
\hline Pašman & 2711 & 2845 & 134 & 104,9 \\
\hline Iž & 557 & 615 & 58 & 110,4 \\
\hline Rava & 98 & 117 & 19 & 119,4 \\
\hline Dugi otok & 1772 & 1655 & -117 & 93,4 \\
\hline Vrgada & 242 & 249 & 7 & 102,9 \\
\hline Sjevernodalmatinski otoci & 22.565 & 24.615 & 2050 & 109,1 \\
\hline Dalmatinski otoci & 83.731 & 85.249 & 1518 & 101,8 \\
\hline Hrvatski otoci & 122.418 & 124.955 & 2537 & 102,1 \\
\hline
\end{tabular}

Izvor: Popis stanovništva, kućanstava i stanova 2001., Stanovništvo prema spolu i starosti, po naseljima, Državni zavod za statistiku, Zagreb, 2001., http://www.dzs.hr/Hrv/censuses/ Census2001/Popis/H01_01_01/H01_01_01.html; Popis stanovništva, kućanstava i stanova 2011., Stanovništvo prema starosti i spolu po naseljima, Državni zavod za statistiku, Zagreb, 2011., http://wwww.dzs.hr/Hrv/censuses/census2011/results/htm/H01_01_01/H01_01_01.html.

U usporedbi dalmatinskih otočnih podskupina vidljiva je korelacija općega kretanja broja stanovnika i geografskog položaja skupina. Tako se na sjevernodalmatinskim otocima uočava visoka stopa porasta broja stanovnika, na srednjodalmatinskima zatječemo stagnaciju, odnosno blagi porast, dok se na južnoj dalmatinskoj otočnoj podskupini suočavamo s već umjerenom depopulacijom. Evidentno je da se pozitivni predznaci ukupnoga kre- 
tanja smanjuju promatramo li otoke od sjevera prema jugu, gdje se transformiraju u negativne. Tako u najjužnijoj skupini u proteklome desetljetnom razdoblju ne postoji otok na kojem se broj stanovnika povećao.

Tablica 4. Kretanje broja stanovnika srednjodalmatinskih otoka od 2001. do 2011.

Table 4. Population trends on Central Dalmatian islands, 2001-2011

\begin{tabular}{|c|c|c|c|c|}
\hline \multirow{2}{*}{ Otok/otočna skupina } & \multicolumn{2}{|c|}{ Broj stanovnika } & \multirow{2}{*}{$\begin{array}{l}\text { Apsolutna } \\
\text { razlika } \\
\text { (2011. - } \\
\text { 2001.) }\end{array}$} & \multirow{2}{*}{$\begin{array}{c}\text { Indeks } \\
\text { popisne } \\
\text { promjene }\end{array}$} \\
\hline & 2001. & 2011. & & \\
\hline Murter & 5060 & 4895 & -165 & 96,7 \\
\hline Kornati & 7 & 19 & 12 & 271,4 \\
\hline Prvić & 453 & 403 & -50 & 89,0 \\
\hline Zlarin & 276 & 284 & 8 & 102,9 \\
\hline Krapanj & 237 & 170 & -67 & 71,7 \\
\hline Kaprije & 143 & 189 & 46 & 132,2 \\
\hline Žirje & 124 & 103 & -21 & 83,1 \\
\hline Drvenik mali & 54 & 87 & 33 & 161,1 \\
\hline Drvenik veli & 168 & 150 & -18 & 89,3 \\
\hline Čiovo & 5387 & 5908 & 521 & 109,7 \\
\hline Šolta & 1479 & 1700 & 221 & 114,9 \\
\hline Brač & 14.031 & 13.956 & -75 & 99,5 \\
\hline Hvar & 11.103 & 11.077 & -26 & 99,8 \\
\hline Vis & 3617 & 3445 & -172 & 95,2 \\
\hline Biševo & 19 & 15 & -4 & 78,9 \\
\hline Sveti Andrija & 1 & 0 & -1 & 0,0 \\
\hline Srednjodalmatinski otoci & 42.159 & 42.401 & 242 & 100,6 \\
\hline Dalmatinski otoci & 83.731 & 85.249 & 1518 & 101,8 \\
\hline Hrvatski otoci & 122.418 & 124.955 & 2537 & 102,1 \\
\hline
\end{tabular}

Izvor: Popis stanovništva, kućanstava i stanova 2001., Stanovništvo prema spolu i starosti, po naseljima, Državni zavod za statistiku, Zagreb, 2001., http://www.dzs.hr/Hro/censuses/ Census2001/Popis/H01_01_01/H01_01_01.html; Popis stanovništva, kućanstava $i$ stanova 2011., Stanovništvo prema starosti i spolu po naseljima, Državni zavod za statistiku, Zagreb, 2011., http://www.dzs.hr/Hrv/censuses/census2011/results/htm/H01_01_01/H01_01_01.html. 
Tablica 5. Kretanje broja stanovnika južnodalmatinskih otoka od 2001. do 2011.

Table 5. Population trends on Southern Dalmatian islands, 2001-2011

\begin{tabular}{|c|c|c|c|c|}
\hline \multirow{2}{*}{ Otok/otočna skupina } & \multicolumn{2}{|c|}{ Broj stanovnika } & \multirow{2}{*}{$\begin{array}{l}\text { Apsolutna } \\
\text { razlika (2011. } \\
\text { - 2001.) }\end{array}$} & \multirow{2}{*}{$\begin{array}{l}\text { Indeks } \\
\text { popisne } \\
\text { promjene }\end{array}$} \\
\hline & 2001. & 2011. & & \\
\hline Korčula & 16.182 & 15.522 & -660 & 95,9 \\
\hline Lastovo & 835 & 792 & -43 & 94,9 \\
\hline Mljet & 1111 & 1088 & -23 & 97,9 \\
\hline Šipan & 436 & 419 & -17 & 96,1 \\
\hline Lopud & 269 & 249 & -20 & 92,6 \\
\hline Koločep & 174 & 163 & -11 & 93,7 \\
\hline Južnodalmatinski otoci & 19.007 & 18.233 & -774 & 95,9 \\
\hline Dalmatinski otoci & 83.731 & 85.249 & 1518 & 101,8 \\
\hline Hrvatski otoci & 122.418 & 124.955 & 2537 & 102,1 \\
\hline
\end{tabular}

Izvor: Popis stanovništva, kućanstava i stanova 2001., Stanovništvo prema spolu $i$ starosti, po naseljima, Državni zavod za statistiku, Zagreb, 2001., http://www.dzs.hr/Hrv/censuses/ Census2001/Popis/H01_01_01/H01_01_01.html; Popis stanovništva, kućanstava i stanova 2011., Stanovništvo prema starosti i spolu po naseljima, Državni zavod za statistiku, Zagreb, 2011., http://www.dzs.hr/Hrv/censuses/census2011/results/htm/H01_01_01/H01_01_01.html.

Usporedi li se dinamika ukupnoga kretanja stanovništva pojedinih skupina s međupopisnim razdobljem 1991. - 2001. (vidjeti u: Lajić i Mišetić, 2006: 53), vidljiv je nastavak zatečenog trenda i u najnovijem razdoblju jer je sada kao i prije negativna stopa ukupnoga kretanja zabilježena kod stanovništva južnodalmatinskih otoka, dok su sjevernodalmatinski i srednjodalmatinski imali pozitivne predznake. Pritom valja istaknuti da su se vrijednosti kod ove potonje skupine osjetno smanjile, dok se na sjevernim otocima dalmatinskog arhipelaga stopa u novije vrijeme čak i povećala. No ako izdvojimo premoštene otoke, intenzitet promjena te čak i predznak kretanja broja stanovnika bitno se mijenjaju. U tom slučaju sjevernodalmatinski otoci u posljednjemu međupopisnom desetljeću bilježe porast broja stanovnika od samo $0,4 \%$, dok srednjodalmatinski doživljavaju pad broja stanovnika od $0,2 \%$, a ne porast od $0,6 \%$.

Značajni rast broja stanovnika premoštenih otoka, kao i njihov udio u ukupnoj otočnoj populaciji rastu već treće međupopisno razdoblje zaredom (tablica 6). O snazi demografskog rasta premoštenih otoka dovoljno govore činjenice da je u sva tri međupopisna razdoblja broj stanovnika rastao za 
više od deset posto, a njihov je udio u ukupnoj otočnoj populaciji s četvrtine 1981. narastao na trećinu 2011. godine. U posljednjemu međupopisnom razdoblju skupina premoštenih otoka ostvarila je najveći rast broja stanovnika u odnosu na ostale analizirane skupine ${ }^{11}$. Povećanje je tolikih razmjera da izuzećem tih pseudootoka iz hrvatske otočne skupine dobivamo stanje gdje se može ustvrditi da preostali nepremošteni otoci i nadalje prolaze depopulacijsko razdoblje. Naime broj stanovnika na njima zabilježen 2001. godine, 84.107, opada 2011. na 82.710, što znači pad od 1,7\%. Budući da je po brojnim značajkama upitno premoštene otoke svrstavati u uobičajeno poimanje otoka i ravnopravno pripadanje pojedinim otočnim skupinama, možemo konstatirati da je metodološki upitno tvrditi da je taj popis stanovništva pokazao da je zaustavljena otočna hrvatska depopulacija. Osim toga broj kuća za odmor neusporedivo je veći na premoštenima u usporedbi s nepremoštenim otocima, a broj vikendaša u neposrednoj je korelaciji s udjelom »fiktivnog stanovništva", koje ovdje ne isključujemo iz pretpostavke stvarnoga kretanja broja otočnog stanovništva. ${ }^{12}$

Tablica 6. Kretanje broja i udjela stanovnika premoštenih, nepremoštenih i malih otoka od 1981. do 2011.

Table 6. Changes in the number and share of the population on the bridged, unbridged and small islands, 1981-2011

\begin{tabular}{|c|c|c|c|c|c|c|c|}
\hline \multirow{2}{*}{ Otočna skupina } & & \multicolumn{4}{|c|}{ Broj stanovnika } & \multicolumn{2}{|c|}{$\begin{array}{c}\text { Indeks popisne } \\
\text { promjene }\end{array}$} \\
\hline & & 1981. & 1991. & 2001. & 2011. & $\begin{array}{l}2011 . / \\
1981 .\end{array}$ & $\begin{array}{l}2011 . / \\
2001 .\end{array}$ \\
\hline \multirow{2}{*}{$\begin{array}{l}\text { Premošteni } \\
\text { otoci }\end{array}$} & aps. & 27.580 & 30.975 & 38.313 & 42.245 & \multirow{2}{*}{153,2} & \multirow{2}{*}{110,3} \\
\hline & $\%$ & 25,2 & 27,6 & 31,3 & 33,8 & & \\
\hline \multirow{2}{*}{$\begin{array}{l}\text { Nepremošteni } \\
\text { otoci }\end{array}$} & aps. & 81.756 & 81.451 & 84.105 & 82.710 & \multirow{2}{*}{101,3} & \multirow{2}{*}{98,3} \\
\hline & $\%$ & 74,7 & 72,4 & 68,7 & 66,2 & & \\
\hline
\end{tabular}

11 Ovdje valja napomenuti da se u skupini premoštenih otoka izdvaja otok Murter, koji je jedini u međupopisnom razdoblju 2001. - 2011. zabilježio pad broja stanovnika (2011. popisano je 165 Murterana manje negoli 2001.).

12 Za ilustraciju možemo navesti podatke dobivene popisom stanovništva 2001. gdje je samo na malom otoku Viru registrirano 5960 vikendica, dok je ukupno na srednjodalmatinskim otocima Braču, Visu, Hvaru i Šolti taj broj bio 8744 (Popis stanovništva, kućanstava i stanova 2001., Stanovi prema načinu korištenja, po naseljima, CD-ROM, Državni zavod za statistiku, Zagreb, 2004.). 


\begin{tabular}{|c|c|c|c|c|c|c|c|}
\hline \multirow{2}{*}{\multicolumn{2}{|c|}{ Otočna skupina }} & \multicolumn{4}{|c|}{ Broj stanovnika } & \multicolumn{2}{|c|}{$\begin{array}{c}\text { Indeks popisne } \\
\text { promjene }\end{array}$} \\
\hline & & 1981. & 1991. & 2001. & 2011. & $\begin{array}{c}2011 . / \\
1981 .\end{array}$ & $\begin{array}{c}2011 . / \\
2001 .\end{array}$ \\
\hline \multirow{2}{*}{ Mali otoci } & aps. & 5894 & 4462 & 4665 & 4587 & \multirow{2}{*}{77,8} & \multirow{2}{*}{98,3} \\
\hline & $\%$ & 5,4 & 4,0 & 3,8 & 3,7 & & \\
\hline \multicolumn{2}{|c|}{ Hrvatski otoci } & 109.336 & 112.426 & 122.418 & 124.955 & 114,4 & 102,1 \\
\hline
\end{tabular}

Izvor: Popis stanovništva, domaćinstava i stanova 1981., Stanovništvo po naseljima, općinama i zajednicama općina, Dokumentacija 553, Republički zavod za statistiku, Zagreb, 1984.; Popis stanovništva, domaćinstava, stanova i poljoprivrednih gospodarstava, 31. 3. 1991., Stanovništvo u zemlji i u inozemstou po naseljima, Dokumentacija 911, Državni zavod za statistiku, Zagreb, 1996.; Popis stanovništva, kućanstava i stanova 2001., Stanovništvo prema spolu i starosti, po naseljima, Državni zavod za statistiku, Zagreb, 2001.,http://wwww. dzs.hr/Hrv/censuses/Census2001/Popis/H01_01_01/H01_01_01.html; Popis stanovništva, kućanstava $i$ stanova 2011., Stanovništvo prema starosti i spolu po naseljima, Državni zavod za statistiku, Zagreb, 2011., http://www.dzs.hr/Hrv/censuses/census2011/results/htm/ H01_01_01/H01_01_01.html.

Apsolutni pokazatelji promjene broja stanovnika malih hrvatskih otoka pokazuju da su se u međupopisnim razdobljima od 1981. do 2011. izmjenjivala negativna i pozitivna kretanja, dok se relativni pokazatelj (udio stanovnika malih otoka u ukupnoj hrvatskoj otočnoj populaciji) od popisa do popisa samo smanjivao (tablica 6). Pad broja stanovnika u posljednjemu međupopisnom razdoblju ide $u$ prilog tvrdnjama da porast populacije na malim otocima zabilježen između 1991. i 2001. »ipak nije u potpunosti rezultat pozitivnih demografskih kretanja već i tzv. 'administrativnog' doseljavanja« (Faričić, Graovac i Čuka, 2010: 155), jer kada se priljev »fiktivnog stanovništva « smanjio, prevladali su učinci prirodnoga kretanja stanovništva.

\section{PRIRODNO KRETANJE STANOVNIŠTVA HRVATSKIH OTOKA OD 2001. DO 2011.}

Uspoređujući biodinamičke značajke otočne populacije u proteklih deset godina s onima koje su obilježavale razdoblje 1991. - 2001. ${ }^{13}$, možemo zaključiti da je došlo do daljnjeg pada stope nataliteta i ukupnog broja otočnog rađanja, smanjili su se stopa mortaliteta i broj umrlih osoba, što je rezultiralo povećanjem prirodnog pada otočnog stanovništva.

13 Usporediti s Nejašmić, 2000. i Lajić i Mišetić, 2006. 
Može se konstatirati da je razina stopa otočnog nataliteta $u$ prvom desetljeću novog tisućljeća za desetak posto manja nego što je bila na razini Republike, a razina stopa mortaliteta gotovo viša za petnaestak posto nego što je bila u cijeloj Hrvatskoj. ${ }^{14}$ Kada se analiziraju apsolutni pokazatelji, vidi se da su u prvom desetljeću 21. stoljeća na hrvatskom otočju prirodnom depopulacijom izgubljena 5532 stanovnika, što bi po populacijskoj masi bio deseti otok po veličini (smjestio bi se između Čiova i Murtera), odnosno prosječni godišnji gubitak od 553 stanovnika ili dvadeseti otok po veličini (između Iža i Šipana). Da nije bilo pozitivnoga migracijskog salda (koji velikim dijelom pripisujemo evidentiranju »fiktivnog stanovništva«), na hrvatskim otocima u proteklih deset godina pod utjecajem postojećeg režima bioreprodukcije broj stanovnika smanjio bi se na 116.886. Osnovni problem prirodnoga kretanja nalazi se u niskoj razini nataliteta, a ne visokoj razini mortaliteta (tablica 7; slika 1). To govori da naši otoci imaju suženu fertilnu bazu, preokrenutu »dobnu piramidu«, što se osim reproduktivnog deficita odražava i na lošim pokazateljima udjela radno aktivnog stanovništva u ukupnome, visokim koeficijentima dobne ovisnosti i visokom stupnju uzdržavane populacije. No analizira li se grafički prikaz prirodnoga kretanja, jasno je vidljiv pozitivni linearni trend stopa prirodne promjene. Ta je svojevrsna kontradiktornost, nažalost, obilježje samo prikazane dekade (nešto niže stope prirodne promjene u prvom dijelu analiziranog razdoblja), a ne i trajniji smjer razvoja.

Alarmantna je demografska činjenica da je na svim našim otočnim skupinama umiranje neusporedivo dominantnija biološka pojava u odnosu na otočno rađanje. To nepovoljno stanje u bližoj budućnosti multiplicirat će još izrazitije negativne procese ne samo $u$ demografskom smislu već i u brojnim društveno-gospodarskim i psihološkim otočnim domenama. Razina stopa nataliteta na svim otočnim skupinama nalazi se u grupi niskog nataliteta, dok natalitet sjevernodalmatinske skupine svrstavamo u kategoriju vrlo niskog nataliteta.

14 Izvor: Prirodno kretanje stanovništva Republike Hrvatske, po naseljima, za godišta od 2001. do 2011., tablogrami, Državni zavod za statistiku, Zagreb. 
Tablica 7. Prirodno kretanje na hrvatskim otočnim skupinama od 2001. do 2011.

Table 7. Natural change on Croatian island groups, 2001-2011

\begin{tabular}{lccccccc}
\hline Otočna skupina & $\mathbf{N}$ & $\mathbf{M}$ & $\mathbf{P P}$ & $\mathbf{V}_{\mathbf{i}}$ & $\begin{array}{c}\mathbf{n} \\
\mathbf{( \% o})\end{array}$ & $\begin{array}{c}\mathbf{m} \\
\mathbf{( \% o}\end{array}$ & $\begin{array}{c}\mathbf{p p} \\
\mathbf{( \% o}\end{array}$ \\
\hline Kvarnerski otoci & 3445 & 4490 & -1045 & 76,7 & 8,8 & 11,5 & $-2,7$ \\
\hline $\begin{array}{l}\text { Sjevernodalmatinski } \\
\text { otoci }\end{array}$ & 1838 & 3459 & -1621 & 53,1 & 7,8 & 14,7 & $-6,9$ \\
\hline $\begin{array}{l}\text { Srednjodalmatinski } \\
\text { otoci }\end{array}$ & 3505 & 5634 & -2129 & 62,2 & 8,3 & 13,3 & $-5,0$ \\
\hline $\begin{array}{l}\text { Južnodalmatinski } \\
\text { otoci }\end{array}$ & 1673 & 2410 & -737 & 69,4 & 9,0 & 12,9 & $-4,0$ \\
\hline $\begin{array}{l}\text { Dalmatinski otoci } \\
\text { Premošteni otoci }\end{array}$ & 7016 & 11.503 & -4487 & 61,0 & 8,3 & 13,6 & $-5,3$ \\
\hline $\begin{array}{l}\text { Nepremošteni } \\
\text { otoci }\end{array}$ & 6512 & 4687 & -1175 & 74,9 & 8,7 & 11,6 & $-2,9$ \\
\hline Mali otoci & 219 & 1181 & -962 & 18,5 & 4,7 & 25,5 & $-20,8$ \\
\hline Hrvatski otoci & $\mathbf{1 0 . 4 6 1}$ & $\mathbf{1 5 . 9 9 3}$ & -5532 & $\mathbf{6 5 , 4}$ & $\mathbf{8 , 5}$ & $\mathbf{1 2 , 9}$ & $-\mathbf{4 , 5}$ \\
\hline
\end{tabular}

Izvor: Prirodno kretanje stanowništva Republike Hrvatske, po naseljima za godišta od 2001. do 2011., tablogrami, Državni zavod za statistiku, Zagreb.

Slika 1. Prirodno kretanje stanovništva hrvatskih otoka od 2001. do 2011. Figure 1. Natural change on Croatian islands, 2001-2011

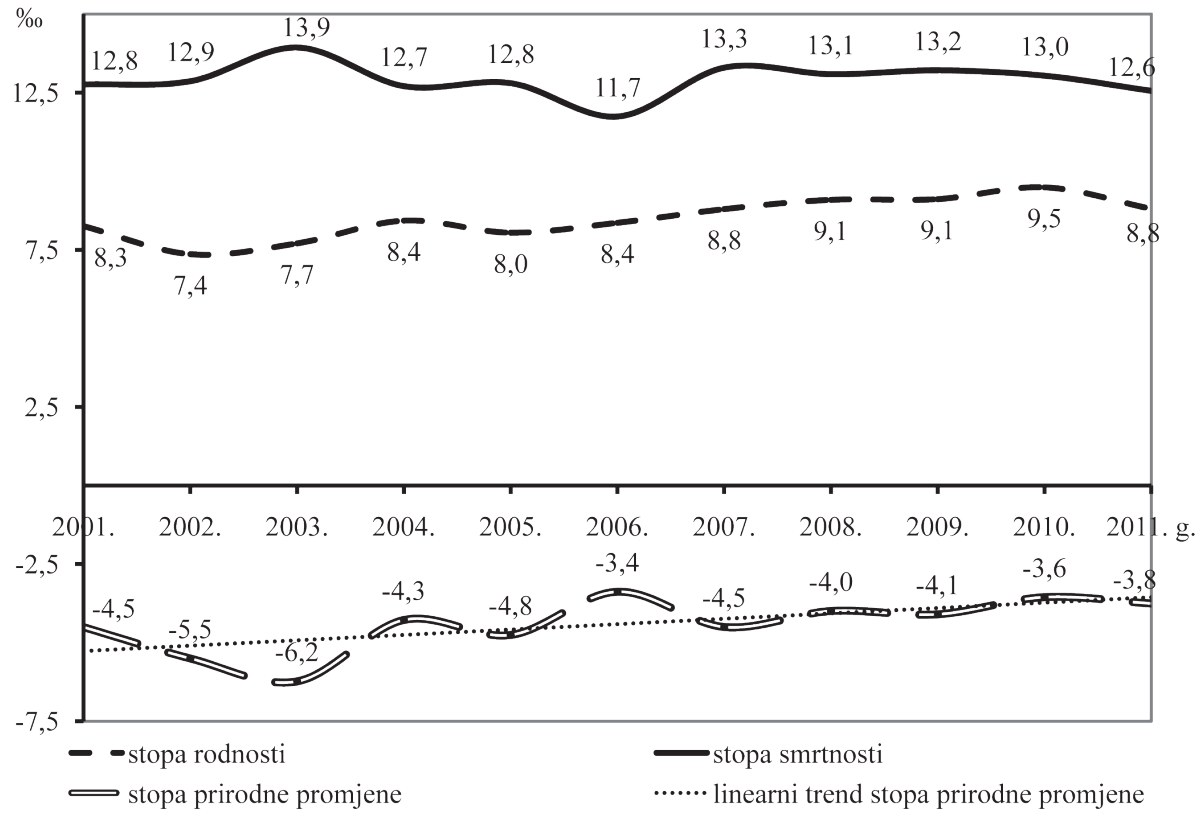


Prirodno kretanje stanovništva otočnoga, pretežno turističkog prostora dovodi u izvjesnu sumnju vjerodostojnost statističkih popisnih podataka jer povećanje broja stanovnika koje je nastalo migracijskim kretanjima trebalo bi polučiti barem minimalni rast nataliteta. To se nije dogodilo, što potvrđuje pretpostavku da su se na prijelazu stoljeća vlasnici kuća za odmor formalno prijavljivali kao stalno stanovništvo, pa porast njihova broja ne prati adekvatno povećanje potomstva. Izuzetno niski natalitet zabilježen je u skupini malih otoka, kod kojih je evidentirana i ekstremno visoka stopa mortaliteta. Proizlazi da je u proteklom desetljeću svaki četvrti stanovnik malih hrvatskih otoka preminuo, što ujedno govori i o vrlo nepovoljnoj dobnoj strukturi stanovništva te skupine. Najviša stopa nataliteta zabilježena je kod populacije koja živi na premoštenim otocima, kod kojih je i najniža stopa mortaliteta. No i kod te populacije mortalitet je nadmašio razinu rađanja te se suočavamo s prirodnim padom. Takvo kretanje biodinamičkih sastavnica otočnih skupina očekivano rezultira i formiranjem vitalnog indeksa ispod vrijednosti 100. Ovdje se uočava izuzetno niska razina tog pokazatelja, to jest međuodnosa ukupnog rađanja i umiranja kod stanovništva malih otoka, koji je iznosio 18,5, što ne daje nikakve nade $\mathrm{u}$ takvu biodinamičkom režimu održanja populacije koja ide prema konačnom izumiranju.

Tablica 8. Prirodno kretanje na odabranim ${ }^{\circ}$ hrvatskim otocima od 2001. do 2011.

Table 8. Natural change on the selected Croatian islands, 2001-2011

\begin{tabular}{lrrrrrrr}
\hline Otok & $\mathbf{N}$ & $\mathbf{M}$ & $\mathbf{P P}$ & $\mathbf{V}_{\mathbf{i}}$ & $\begin{array}{c}\mathbf{n} \\
\mathbf{( \% o}\end{array}$ & $\begin{array}{c}\mathbf{m} \\
\mathbf{( \% o}\end{array}$ & $\begin{array}{c}\mathbf{p p} \\
\mathbf{( \% o}\end{array}$ \\
\hline Vir & 235 & 189 & 46 & 124,3 & 10,2 & 8,2 & 2,0 \\
\hline Čiovo & 516 & 506 & 10 & 102,0 & 9,1 & 9,0 & 0,2 \\
\hline Lošinj & 663 & 766 & -103 & 86,6 & 8,6 & 10,0 & $-1,3$ \\
\hline Rab & 890 & 1017 & -127 & 87,5 & 9,5 & 10,8 & $-1,4$ \\
\hline Krk & 1632 & 2170 & -538 & 75,2 & 8,8 & 11,7 & $-2,9$ \\
\hline Korčula & 1479 & 1962 & -483 & 75,4 & 9,3 & 12,4 & $-3,0$ \\
\hline Brač & 1205 & 1656 & -451 & 72,8 & 8,6 & 11,8 & $-3,2$ \\
\hline Hvar & 965 & 1369 & -404 & 70,5 & 8,7 & 12,3 & $-3,6$ \\
\hline Pag & 717 & 1101 & -384 & 65,1 & 8,2 & 12,6 & $-4,4$ \\
\hline Hrvatski otoci & $\mathbf{1 0 . 4 6 1}$ & $\mathbf{1 5 . 9 9 3}$ & $-\mathbf{5 5 3 2}$ & $\mathbf{6 5 , 4}$ & $\mathbf{8 , 5}$ & $\mathbf{1 2 , 9}$ & $\mathbf{- 4 , 5}$ \\
\hline Pašman & 240 & 377 & -137 & 63,7 & 8,6 & 13,6 & $-4,9$ \\
\hline Cres & 239 & 430 & -191 & 55,6 & 7,6 & 13,7 & $-6,1$ \\
\hline Murter & 412 & 721 & -309 & 57,1 & 8,3 & 14,5 & $-6,2$ \\
\hline
\end{tabular}




\begin{tabular}{lrrrcccc}
\hline Otok & $\mathbf{N}$ & $\mathbf{M}$ & $\mathbf{P P}$ & $\mathbf{V}_{\mathbf{i}}$ & $\begin{array}{c}\mathbf{n} \\
\mathbf{( \% o}\end{array}$ & $\begin{array}{c}\mathbf{m} \\
\mathbf{( \% o )}\end{array}$ & $\begin{array}{c}\mathbf{p p} \\
\mathbf{( \% o})\end{array}$ \\
\hline Lastovo & 65 & 116 & -51 & 56,0 & 8,0 & 14,3 & $-6,3$ \\
\hline Ugljan & 479 & 958 & -479 & 50,0 & 7,8 & 15,7 & $-7,8$ \\
\hline Vis & 263 & 653 & -390 & 40,3 & 7,4 & 18,5 & $-11,1$ \\
\hline Mljet & 63 & 191 & -128 & 33,0 & 5,7 & 17,4 & $-11,7$ \\
\hline Dugi otok & 102 & 326 & -224 & 31,3 & 6,0 & 19,0 & $-13,0$ \\
\hline Šolta & 77 & 304 & -227 & 25,3 & 4,8 & 19,1 & $-14,3$ \\
\hline
\end{tabular}

Izvor: Prirodno kretanje stanovništva Republike Hrvatske, po naseljima, za godišta od 2001. do 2011., tablogrami, Državni zavod za statistiku, Zagreb.

Kad se istraživanje spusti na nižu teritorijalnu razinu, prirodna depopulacija postaje još upečatljivija jer od 2001. do 2011. tek na dva otoka (Vir i Čiovo) natalitet nadvisuje mortalitet. No kako su oba otoka premoštena i pripadaju skupini pseudootoka, legitimno je reći da je na svim hrvatskim otocima u posljednjemu međupopisnom razdoblju bila prisutna prirodna depopulacija. Posebno zabrinjava činjenica da se na našim najnapučenijim otocima (Krk, Korčula, Brač i Hvar), jedinim s više od 10.000 stanovnika, koji čine čak $48 \%$ ukupne otočne populacije, vrijednost vitalnog indeksa za razdoblje 2001. - 2011. kretala od 75,4 (Korčula) do 70,2 (Hvar).

\section{MIGRACIJSKI SALDO STANOVNIŠTVA HRVATSKIH OTOKA OD 2001. DO 2011.}

I u posljednjemu međupopisnom razdoblju na hrvatskom otočju registriran je pozitivni migracijski saldo, koji je zadržao gotovo jednaki intenzitet kao u prethodnom desetljeću, s prosječnom godišnjom stopom od 6,5\%. Sve promatrane otočne skupine, izuzevši južnodalmatinsku, u proteklomu međupopisnom razdoblju obilježava snažniji mehanički priljev stanovništva nego odseljavanje otočana. Poznajući stanje na otocima te pojavu već naglašenoga fiktivnog prijavljivanja boravišta na otočju, opetuje se pitanje stvarne pozicije migracijskog salda u ukupnom kretanju stanovništva, dok je kategorija prirodnoga kretanja bliža objektivnijem stanju. Slikovito rečeno, pozitivni migracijski saldo takva je obujma da se stanovništvo naših otoka u proteklih deset godina zbog te sastavnice ukupnoga kretanja povećalo za broj stanovnika veličine otoka koji bi se smjestio na sedmo mjesto po veličini populacije, odnosno između Paga i Lošinja. Kad se suprotstave pozitivna stopa migracija i negativne stope prirodnoga kretanja, vidljivo je da pozitivni migracijski saldo poništava negativne tendencije bioreproduk- 
cije na svim otočnim podskupinama osim južnodalmatinske. Dok je kod kvarnerske i sjevernodalmatinske skupine migracijski saldo više nego dvostruko veći od prirodnog pada, kod srednjodalmatinske skupine prirodni se pad približio pozitivnome migracijskom saldu, što je rezultiralo tek blagim porastom općega kretanja. Na južnodalmatinskim otocima demografsko je stanje znatno nepovoljnije jer su obje sastavnice ukupnoga kretanja negativne, što logično rezultira i krajnje negativnim predznakom općega kretanja stanovništva. Gotovo stoljetno iseljavanje s malih otoka, koje ih je dovelo do stanja nemoguće bioreprodukcije jer su nestale fertilne kohorte, u novijem razdoblju formalno visoke stope imigracije donekle ublažavaju denatalitet, odnosno visoku stopu mortaliteta, ali kao i kod drugih otočnih skupina ovdje je riječ o priljevu starijeg stanovništva, i to u visokoj mjeri jer je pozitivna stopa migracija, uz sjevernodalmatinsku, najviša među malim otočnim skupinama, to jest »malim otocima $«$.

Tablica 9. Migracijski saldo stanovništva hrvatskih otoka i otočnih skupina od 2001. do 2010.

Table 9. Net migration of the population of Croatian islands and groups of islands, 2001-2011

\begin{tabular}{|c|c|c|c|c|c|}
\hline \multirow{2}{*}{ Otočna skupina } & \multicolumn{2}{|c|}{ Broj stanovnika } & \multirow{2}{*}{$\mathbf{P P}$} & \multirow{2}{*}{ MS } & \multirow{2}{*}{$\begin{array}{c}\mathrm{ms} \\
(\% \mathrm{o})\end{array}$} \\
\hline & 2001. & 2011. & & & \\
\hline Kvarnerski otoci & 38.687 & 39.706 & -1045 & 2064 & 5,3 \\
\hline Sjevernodalmatinski otoci & 22.565 & 24.615 & -1621 & 3671 & 15,6 \\
\hline Srednjodalmatinski otoci & 42.159 & 42.401 & -2129 & 2371 & 5,6 \\
\hline Južnodalmatinski otoci & 19.007 & 18.233 & -737 & -37 & $-0,2$ \\
\hline Dalmatinski otoci & 83.731 & 85.249 & -4487 & 6005 & 7,1 \\
\hline Premošteni otoci & 38.313 & 42.245 & -1175 & 5107 & 12,7 \\
\hline Nepremošteni otoci & 84.105 & 82.710 & -4357 & 2962 & 3,6 \\
\hline Mali otoci & 4665 & 4587 & -962 & 884 & 19,1 \\
\hline Hrvatski otoci & 122.418 & 124.955 & -5532 & 8069 & 6,5 \\
\hline
\end{tabular}

Izvor: Popis stanovništva, kućanstava i stanova 2001., Stanovništvo prema spolu $i$ starosti, po naseljima, Državni zavod za statistiku, Zagreb, 2001., http://www.dzs.hr/Hro/censuses/ Census2001/Popis/H01_01_01/H01_01_01.html; Popis stanovništva, kućanstava i stanova 2011., Stanovništvo prema starosti $\bar{i}$ spolu po naseljima, Državni zavod za statistiku, Zagreb, 2011., http://www.dzs.hr/Hro/censuses/census2011/results/htm/H01_01_01/H01_01_01. html; Prirodno kretanje stanovništva Republike Hrvatske, po naseljima za godišta od $2 \overline{0} 01$. do 2010., tablogrami, Državni zavod za statistiku, Zagreb. 
Tablica 10. Migracijski saldo stanovništva odabranih hrvatskih otoka od 2001. do 2011.

Table 10. Net migration of the population of the selected Croatian islands, 2001-2011

\begin{tabular}{|c|c|c|c|c|c|}
\hline \multirow{2}{*}{ Otok } & \multicolumn{2}{|c|}{ Broj stanovnika } & \multirow{2}{*}{$\mathbf{P P}$} & \multirow{2}{*}{ MS } & \multirow{2}{*}{$\underset{(\%)}{\mathrm{ms}}$} \\
\hline & 2001. & 2011. & & & \\
\hline Vir & 1608 & 3000 & 46 & 1346 & 58,4 \\
\hline Čiovo & 5387 & 5908 & 10 & 511 & 9,0 \\
\hline Lošinj & 7771 & 7587 & -103 & -81 & $-1,1$ \\
\hline $\mathrm{Rab}$ & 9480 & 9328 & -127 & -25 & $-0,3$ \\
\hline Krk & 17.860 & 19.383 & -538 & 2061 & 11,1 \\
\hline Korčula & 16.182 & 15.522 & -483 & -177 & $-1,1$ \\
\hline Brač & 14.031 & 13.954 & -451 & 374 & 2,7 \\
\hline Hvar & 11.103 & 11.077 & -404 & 378 & 3,4 \\
\hline Pag & 8398 & 9059 & -384 & 1045 & 12,0 \\
\hline Hrvatski otoci & 122.418 & 124.955 & -5532 & 8069 & 6,5 \\
\hline Pašman & 2711 & 2845 & -137 & 271 & 9,8 \\
\hline Cres & 3184 & 3079 & -191 & 86 & 2,7 \\
\hline Murter & 5060 & 4895 & -309 & 144 & 2,9 \\
\hline Lastovo & 835 & 792 & -51 & 8 & 1,0 \\
\hline Ugljan & 6164 & 6049 & -479 & 364 & 6,0 \\
\hline Vis & 3617 & 3445 & -390 & 218 & 6,2 \\
\hline Mljet & 1111 & 1088 & -128 & 105 & 9,5 \\
\hline Dugi otok & 1772 & 1655 & -224 & 107 & 6,2 \\
\hline Šolta & 1479 & 1700 & -227 & 448 & 28,2 \\
\hline
\end{tabular}

Izvor: Popis stanovništva, kućanstava i stanova 2001., Stanovništvo prema spolu i starosti, po naseljima, DZS, Zagreb, 2001., http://www.dzs.hr/Hrv/censuses/Census2001/Popis/ H01_01_01/H01_01_01.html; Popis stanovništva, kućanstava i stanova 2011., Stanovništvo prema starosti i spolu po naseljima, DZS, Zagreb, 2011., http://www.dzs.hr/Hrv/censuses/ census2011/results/htm/H01_01_01/H01_01_01.html; Prirodno kretanje stanovništva Republike Hrvatske, po naseljima za godišta od 2001. do 2010., tablogrami, Državni zavod za statistiku, Zagreb.

Kako je već navedeno, imigracija stanovništva na otoke u pozitivnoj je korelaciji s brojem stanova za odmor na njima. Stoga i ne čudi što je apsolutna vrijednost migracijskog salda premoštenih otoka više nego četverostruko nadmašila vrijednost prirodnog pada. Dakako, nositelj je takva zbivanja, očekivano, otok Vir. Imigracijska ekspanzija s ostvarenom prosječnom godišnjom stopom od čak 58,4\% nastavak je procesa koji je počeo devedesetih 
godina 20. stoljeća i rezultirao činjenicom da je »...Vir postao sinonim za sve loše što se veže uz izgradnju stanova za odmor « (Miletić, 2006: 48). Tako su samo u posljednjemu međupopisnom razdoblju svi indeksi promjene broja stanova premašili indeks međupopisne promjene broja stanovnika: indeks promjene ukupnog broja stanova iznosio je 194,0 (broj stanova povećao se sa 6573 na 12.750); indeks promjene broja stanova za stalno stanovanje 212,6 (broj stanova povećao se sa 610 na 1297); indeks promjene broja ostalih stanova 192,1 (broj stanova povećao se s 5963 na 11.453) ${ }^{15}$.

\section{TIPOVI OPĆEGA KRETANJA STANOVNIŠTVA HRVATSKIH OTOKA I OTOČNIH SKUPINA OD 2001. DO 2011.}

Međuodnos sastavnica općega kretanja stanovništva neke populacije u određenom razdoblju najlakše se rasvjetljuje tipom općega kretanja stanovništva. Tipovi općega kretanja stanovništva svrstavaju se u dvije osnovne skupine, imigracijsku i emigracijsku (egzodusnu), od kojih svaka ima četiri podtipa. Rezultati govore da u posljednjemu međupopisnom razdoblju sve skupine osim južnodalmatinske pripadaju imigracijskim tipovima visokog eksponenta, što znači da se te populacije donekle regeneriraju slabijom imigracijom. To je značajka cjelokupnoga hrvatskog otočja, koje obilježava trend »slabe regeneracije imigracijom « (Friganović i Pavić, 1973: 22-23; Nejašmić, 2005: 62-63). To obilježje prati obje najznačajnije otočne skupine (kvarnerske i dalmatinske otoke), dok kod izdvojenih skupina (nepremoštenih otoka, malih otoka) te kod stanovništva srednjodalmatinskih otoka za posljednje međupopisno razdoblje određujemo trend obilježja »vrlo slaba obnova imigracijom «. Donekle bolju situaciju zatječemo kod premoštenih otoka i sjevernodalmatinske skupine, kod kojih je popisna promjena vrlo visoke pozitivne stope determinirana visokim stopama migracija, što je i odredilo trend »obnove imigracijom «. Budući da južnodalmatinski otoci imaju sve demografske pokazatelje nepovoljne, a dominira negativna stopa popisne promjene, ta je skupina uvrštena u egzodusne tipove, i to krajnjega, najnepovoljnijeg tipa i trenda, a to je izumiranje stanovništva.

15 Izvor: Popis stanovništva, kućanstava i stanova 2001., Stanovi prema načinu korištenja, po naseljima, CD-ROM, DZS, Zagreb, 2004.; Popis stanovništva, kućanstava i stanova 2011., Proi rezultati, DZS, Zagreb, 2011., http://www.dzs.hr/Hrv/censuses/census2011/firstres/htm/ h11_RH.html. 
Tablica 11. Tipovi općega kretanja stanovništva hrvatskih otoka i otočnih skupina od 2001. do 2011.

Table 11. Types of population trends on Croatian islands and groups of islands, 2001-2011

\begin{tabular}{|c|c|c|c|c|c|}
\hline Otočna skupina & $\begin{array}{c}\text { Stopa } \\
\text { popisne } \\
\text { promjene } \\
(\%)\end{array}$ & $\begin{array}{c}\text { Stopa } \\
\text { prirodne } \\
\text { promjene } \\
(\%)\end{array}$ & $\begin{array}{c}\text { Stopa } \\
\text { migracija } \\
(\% \text { ) }\end{array}$ & Tip & Trend \\
\hline Kvarnerski otoci & 2,6 & $-2,7$ & 5,3 & $\mathrm{I}_{3}$ & $\begin{array}{l}\text { slaba obnova } \\
\text { imigracijom }\end{array}$ \\
\hline $\begin{array}{l}\text { Sjevernodalmatinski } \\
\text { otoci }\end{array}$ & 8,7 & $-6,9$ & 15,6 & $I_{2}$ & $\begin{array}{l}\text { obnova } \\
\text { imigracijom }\end{array}$ \\
\hline $\begin{array}{l}\text { Srednjodalmatinski } \\
\text { otoci }\end{array}$ & 0,6 & $-5,0$ & 5,6 & $I_{3}$ & $\begin{array}{l}\text { slaba obnova } \\
\text { imigracijom }\end{array}$ \\
\hline $\begin{array}{l}\text { Južnodalmatinski } \\
\text { otoci }\end{array}$ & $-4,2$ & $-4,0$ & $-0,2$ & $E_{4}$ & izumiranje \\
\hline Dalmatinski otoci & 1,8 & $-5,3$ & 7,1 & $\mathrm{I}_{3}$ & $\begin{array}{l}\text { slaba obnova } \\
\text { imigracijom }\end{array}$ \\
\hline Premošteni otoci & 9,8 & $-2,9$ & 12,7 & $\mathrm{I}_{2}$ & $\begin{array}{l}\text { obnova } \\
\text { imigracijom }\end{array}$ \\
\hline $\begin{array}{l}\text { Nepremošteni } \\
\text { otoci }\end{array}$ & $-1,7$ & $-5,2$ & 3,6 & $\mathrm{I}_{4}$ & $\begin{array}{l}\text { vrlo slaba } \\
\text { obnova } \\
\text { imigracijom }\end{array}$ \\
\hline Mali otoci & $-1,7$ & $-20,8$ & 19,1 & $\mathrm{I}_{4}$ & $\begin{array}{l}\text { vrlo slaba } \\
\text { obnova } \\
\text { imigracijom }\end{array}$ \\
\hline Hrvatski otoci & 2,1 & $-4,5$ & 6,5 & $\mathrm{I}_{3}$ & $\begin{array}{l}\text { slaba obnova } \\
\text { imigracijom }\end{array}$ \\
\hline
\end{tabular}


Tablica 12. Tipovi općega kretanja stanovništva odabranih hrvatskih otoka od 2001. do 2011.

Table 12. Types of population trends on the selected Croatian islands, 2001-2011

\begin{tabular}{|c|c|c|c|c|c|}
\hline $\begin{array}{l}\text { Otočna } \\
\text { skupina }\end{array}$ & $\begin{array}{c}\text { Stopa } \\
\text { popisne } \\
\text { promjene } \\
(\%)\end{array}$ & $\begin{array}{c}\text { Stopa } \\
\text { prirodne } \\
\text { promjene } \\
(\%)\end{array}$ & $\begin{array}{c}\text { Stopa } \\
\text { migracija } \\
(\% o)\end{array}$ & Tip & Trend \\
\hline Vir & 60,4 & 2,0 & 58,4 & $\mathrm{I}_{1}$ & $\begin{array}{l}\text { ekspanzija } \\
\text { imigracijom }\end{array}$ \\
\hline Čiovo & 9,2 & 0,2 & 9,0 & $\mathrm{I}_{1}$ & $\begin{array}{l}\text { ekspanzija } \\
\text { imigracijom }\end{array}$ \\
\hline Lošinj & $-2,4$ & $-1,3$ & $-1,1$ & $\mathrm{E}_{4}$ & izumiranje \\
\hline Rab & $-1,7$ & $-1,4$ & $-0,3$ & $\mathrm{E}_{4}$ & izumiranje \\
\hline Krk & 8,2 & $-2,9$ & 11,1 & $\mathrm{I}_{2}$ & $\begin{array}{l}\text { obnova } \\
\text { imigracijom }\end{array}$ \\
\hline Korčula & $-4,1$ & $-3,0$ & $-1,1$ & $\mathrm{E}_{4}$ & izumiranje \\
\hline Brač & $-0,5$ & $-3,2$ & 2,7 & $\mathrm{I}_{4}$ & $\begin{array}{l}\text { vrlo slaba obnova } \\
\text { imigracijom }\end{array}$ \\
\hline Hvar & $-0,2$ & $-3,6$ & 3,4 & $\mathrm{I}_{4}$ & $\begin{array}{l}\text { vrlo slaba obnova } \\
\text { imigracijom }\end{array}$ \\
\hline Pag & 7,6 & $-4,4$ & 12,0 & $\mathrm{I}_{2}$ & $\begin{array}{l}\text { obnova } \\
\text { imigracijom }\end{array}$ \\
\hline Hrvatski otoci & 2,1 & $-4,5$ & 6,5 & $\mathbf{I}_{3}$ & $\begin{array}{l}\text { slaba obnova } \\
\text { imigracijom }\end{array}$ \\
\hline Pašman & 4,9 & $-4,9$ & 9,8 & $\mathrm{I}_{2}$ & $\begin{array}{l}\text { obnova } \\
\text { imigracijom }\end{array}$ \\
\hline Cres & $-3,4$ & $-6,1$ & 2,7 & $\mathrm{I}_{4}$ & $\begin{array}{l}\text { vrlo slaba obnova } \\
\text { imigracijom }\end{array}$ \\
\hline Murter & $-3,3$ & $-6,2$ & 2,9 & $\mathrm{I}_{4}$ & $\begin{array}{l}\text { vrlo slaba obnova } \\
\text { imigracijom }\end{array}$ \\
\hline Lastovo & $-5,3$ & $-6,3$ & 1,0 & $\mathrm{I}_{4}$ & $\begin{array}{l}\text { vrlo slaba obnova } \\
\text { imigracijom }\end{array}$ \\
\hline Ugljan & $-1,8$ & $-7,8$ & 6,0 & $\mathrm{I}_{4}$ & $\begin{array}{l}\text { vrlo slaba obnova } \\
\text { imigracijom }\end{array}$ \\
\hline Vis & $-4,8$ & $-11,0$ & 6,2 & $\mathrm{I}_{4}$ & $\begin{array}{l}\text { vrlo slaba obnova } \\
\text { imigracijom }\end{array}$ \\
\hline Mljet & $-2,1$ & $-11,6$ & 9,5 & $\mathrm{I}_{4}$ & $\begin{array}{l}\text { vrlo slaba obnova } \\
\text { imigracijom }\end{array}$ \\
\hline Dugi otok & $-6,9$ & $-13,1$ & 6,2 & $\mathrm{I}_{4}$ & $\begin{array}{l}\text { vrlo slaba obnova } \\
\text { imigracijom }\end{array}$ \\
\hline Šolta & 13,9 & $-14,3$ & 28,2 & $\mathrm{I}_{3}$ & $\begin{array}{l}\text { slaba obnova } \\
\text { imigracijom }\end{array}$ \\
\hline
\end{tabular}


Tipovi općega kretanja stanovništva od 2001. do 2011. najplastičnije pokazuju utjecaj migracija (stvarnih ili fiktivnih) na male otočne populacije. Naime dok su u razdoblju 1961. - 1991. dominirali emigracijski tipovi općega kretanja stanovništva (zabilježeni na 37 otoka ili $84,1 \%$ naseljenih otoka) (Friganović, 2001: 47-51), u posljednjemu međupopisnom razdoblju dominiraju imigracijski tipovi, koji su registrirani na 32 otoka, što čini udio od čak $86,5 \%$ svih naseljenih hrvatskih otoka 2011. No iako se čini da je promjenom dominantnog tipa općega kretanja stanovništva došlo do značajnijih kvantitativnih i kvalitativnih promjena u otočnoj populaciji, to je zapravo privid jer su migracijska kretanja $u$ analiziranom razdoblju uspjela dominantni tip E4 - izumiranje transformirati u dominaciju tipa I4 - vrlo slaba obnova imigracijom.

\section{PROMJENE DOBNOG SASTAVA OTOČNOG STANOVNIŠTVA OD 2001. DO 2011.}

Većim dijelom 20. stoljeća na hrvatskom su otočju dominirali negativni demografski procesi. Dugogodišnja emigracijska kretanja i potom prirodna depopulacija rezultirali su starenjem populacije i slabljenjem biodinamičkih potencijala otočnog stanovništva. Prema Nejašmiću, »...u tako ostarjeloj populaciji dolazi do smanjenja ekonomske aktivnosti, a teško je (negdje i nemoguće) uspostaviti zadovoljavajući i uravnotežen društveni život. To rezultira daljnjim odlaskom preostale mladeži čime se produbljuje sociodemografska depresija te ograničava mogućnost stabiliziranja nepovoljnih demografskih i opće razvojnih tendencija « (Nejašmić, 1992: 31). Nakon emigracijskog razdoblja, kako je već navedeno, u posljednja dva međupopisna razdoblja na hrvatskom je otočju zabilježeno jačanje pozitivne migracijske sastavnice i rast broja stanovnika. Slijedom kauzalnosti odnosa općega kretanja stanovništva i dobno-spolnog sastava bili su očekivani pozitivni pomaci kod pokazatelja dobnog sastava stanovništva. Analize su pokazale da u posljednjem desetljeću 20. stoljeća do toga nije došlo te se stoga smatra da je potvrđena pretpostavka da su u »statističkom naseljavanju« otoka sudjelovali vlasnici kuća za odmor i starija populacija. Rezultati raščlambe općega kretanja stanovništva hrvatskih otoka od 2001. do 2011. pokazali su da je nastavljen trend rasta broja stanovnika temeljen na pojačanoj imigraciji, a svi pokazatelji promjena dobnog sastava govore da se ni u tom pogledu nije ništa promijenilo. Usporedba dobno-spolne piramide 2001. i 2011. pokazuje jasan nastavak starenja otočnog stanovništva, koji se očituje u daljnjem sužavanju baze i širenju gornje polovice piramide. Nastavak trenda možda je 
jasnije vidljiv iz analitičkih pokazatelja dobnog sastava stanovništva. Porast prosječne starosti ukupne otočne populacije u razdoblju 2001. - 2011. (koja je dosegnula vrijednost od čak 45,1 ) zabilježen je i na svim otočnim skupinama u rasponu od 1,8 do 3,2 godine.

Slika 2. Usporedna dobno-spolna piramida stanovništva hrvatskih otoka 2001. i 2011.

Figure 2. Comparative age-sex population pyramid of Croatian islands, 2001-2011

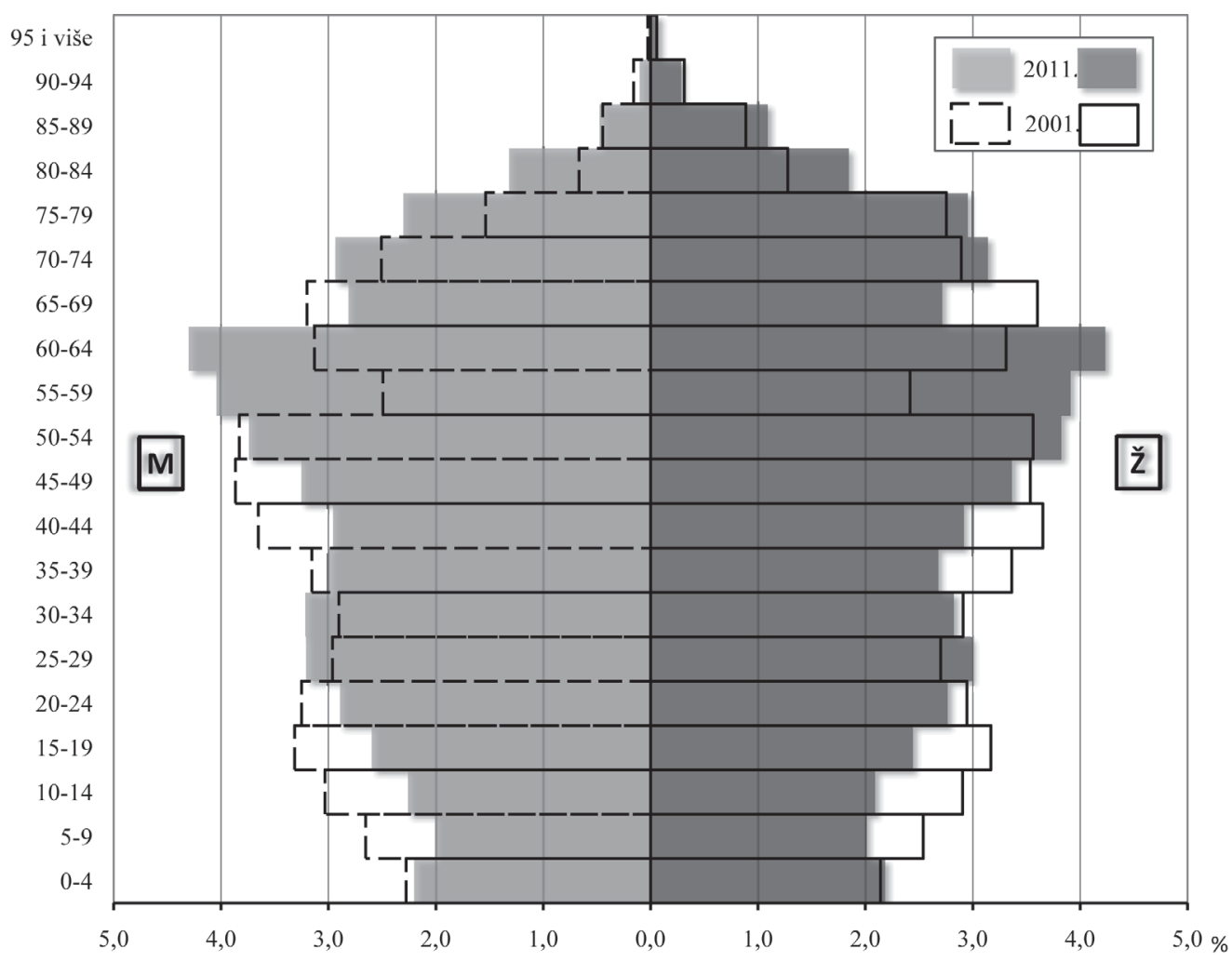


Tablica 13. Pokazatelji dobnog sastava stanovništva hrvatskih otoka i otočnih skupina 2001. i 2011.

Table 13. Age population structure indicators of Croatian islands and groups of islands, 2001-2011

\begin{tabular}{|c|c|c|c|c|c|c|c|c|c|c|}
\hline \multirow{2}{*}{ Otok } & \multicolumn{3}{|c|}{ Prosječna starost } & \multicolumn{3}{|c|}{$\begin{array}{c}\text { Koeficijent starosti } \\
\qquad(65+)\end{array}$} & \multicolumn{3}{|c|}{ Indeks starosti (65+) } & \multirow{2}{*}{ 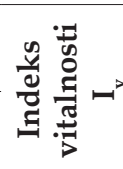 } \\
\hline & 2001. & 2011. & Razlika & 2001. & 2011. & Razlika & 2001. & 2011. & Razlika & \\
\hline $\begin{array}{l}\text { Kvarnerski } \\
\text { otoci }\end{array}$ & 40,6 & 43,6 & 3,0 & 17,1 & 19,2 & 2,1 & 107,4 & 146,6 & 39,3 & 4,7 \\
\hline $\begin{array}{l}\text { Sjevernodalma- } \\
\text { tinski otoci }\end{array}$ & 44,8 & 47,7 & 3,0 & 24,7 & 26,5 & 1,8 & 174,1 & 235,8 & 61,8 & 2,4 \\
\hline $\begin{array}{l}\text { Srednjodalma- } \\
\text { tinski otoci }\end{array}$ & 42,4 & 45,4 & 3,0 & 21,0 & 22,7 & 1,7 & 134,6 & 179,3 & 44,7 & 3,2 \\
\hline $\begin{array}{l}\text { Južnodalmatin- } \\
\text { ski otoci }\end{array}$ & 41,6 & 44,0 & 2,4 & 20,3 & 20,9 & 0,6 & 124,4 & 146,7 & 22,3 & 3,8 \\
\hline $\begin{array}{l}\text { Dalmatinski } \\
\text { otoci }\end{array}$ & 42,9 & 45,7 & 2,9 & 21,8 & 23,4 & 1,6 & 142,0 & 186,0 & 44,0 & 3,1 \\
\hline $\begin{array}{l}\text { Premošteni } \\
\text { otoci }\end{array}$ & 41,2 & 44,4 & 3,2 & 18,6 & 21,0 & 2,5 & 113,9 & 161,3 & 47,3 & 4,3 \\
\hline $\begin{array}{l}\text { Nepremošteni } \\
\text { otoci }\end{array}$ & 42,5 & 45,4 & 2,9 & 21,1 & 22,6 & 1,5 & 139,0 & 179,4 & 40,4 & 3,2 \\
\hline Mali otoci & 53,6 & 55,4 & 1,8 & 39,8 & 38,6 & $-1,2$ & 450,0 & 618,9 & 168,9 & 0,6 \\
\hline Hrvatski otoci & 42,1 & 45,1 & 2,9 & 20,3 & 22,1 & 1,8 & 130,8 & 173,1 & 42,4 & 3,5 \\
\hline
\end{tabular}

Izvor: Popis stanovništva, kućanstava i stanova 2001., Stanovništvo prema spolu i starosti, po naseljima, Državni zavod za statistiku, Zagreb, 2001., http://www.dzs.hr/Hrv/censuses/ Census2001/Popis/H01_01_01/H01_01_01.html; Popis stanovništva, kućanstava i stanova 2011., Stanovništvo prema starosti i spolu po naseljima, Državni zavod za statistiku, Zagreb, 2011., http://www.dzs.hr/Hrv/censuses/census2011/results/htm/H01_01_01/H01_01_01.html. 
Tablica 14. Pokazatelji dobnog sastava stanovništva odabranih hrvatskih otoka 2001. i 2011.

Table 14. Age population structure indicators of the selected Croatian islands, 2001-2011

\begin{tabular}{|c|c|c|c|c|c|c|c|c|c|c|}
\hline \multirow{2}{*}{ Otok } & \multicolumn{3}{|c|}{ Prosječna starost } & \multicolumn{3}{|c|}{$\begin{array}{l}\text { Koeficijent starosti } \\
(65+)\end{array}$} & \multicolumn{3}{|c|}{ Indeks starosti (65+) } & \multirow{2}{*}{ 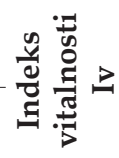 } \\
\hline & 2001. & 2011. & Razlika & 2001. & 2011. & Razlika & 2001. & 2011. & Razlika & \\
\hline Vir & 40,5 & 46,1 & 5,6 & 14,8 & 20,6 & 5,8 & 101,3 & 170,4 & 69,2 & 7,8 \\
\hline Čiovo & 39,4 & 43,2 & 3,9 & 15,1 & 19,6 & 4,5 & 86,7 & 136,2 & 49,4 & 6,7 \\
\hline Lošinj & 38,4 & 42,1 & 3,7 & 13,4 & 15,5 & 2,1 & 78,9 & 118,8 & 39,9 & 6,4 \\
\hline Rab & 40,8 & 43,4 & 2,7 & 16,7 & 19,9 & 3,2 & 109,3 & 140,5 & 31,2 & 5,5 \\
\hline Krk & 40,9 & 44,1 & 3,2 & 17,8 & 19,9 & 2,1 & 110,5 & 156,1 & 45,6 & 4,5 \\
\hline Korčula & 41,1 & 43,6 & 2,5 & 19,4 & 20,2 & 0,7 & 117,9 & 137,3 & 19,4 & 4,2 \\
\hline Brač & 41,2 & 44,6 & 3,3 & 19,2 & 21,6 & 2,4 & 118,7 & 166,2 & 47,5 & 4,1 \\
\hline Hvar & 41,9 & 44,6 & 2,7 & 19,7 & 21,5 & 1,8 & 125,4 & 164,8 & 39,3 & 3,9 \\
\hline $\begin{array}{l}\text { Hrvatski } \\
\text { otoci }\end{array}$ & 42,1 & 45,1 & 2,9 & 20,3 & 22,1 & 1,8 & 130,8 & 173,1 & 42,4 & 3,5 \\
\hline Pag & 42,2 & 45,0 & 2,8 & 20,5 & 23,1 & 2,6 & 124,5 & 178,6 & 54,1 & 3,4 \\
\hline Pašman & 42,7 & 46,1 & 3,4 & 23,0 & 24,5 & 1,5 & 135,3 & 192,3 & 57,0 & 3,1 \\
\hline Cres & 42,5 & 44,7 & 2,2 & 21,1 & 20,7 & $-0,4$ & 145,2 & 167,6 & 22,4 & 3,0 \\
\hline Lastovo & 40,8 & 44,4 & 3,6 & 20,1 & 22,0 & 1,8 & 106,3 & 167,3 & 61,0 & 3,0 \\
\hline Murter & 43,0 & 45,3 & 2,3 & 23,0 & 23,7 & 0,7 & 143,6 & 177,6 & 34,0 & 2,7 \\
\hline Ugljan & 45,4 & 48,4 & 3,0 & 25,0 & 27,2 & 2,2 & 200,4 & 257,5 & 57,1 & 2,3 \\
\hline Vis & 44,3 & 46,4 & 2,1 & 24,8 & 23,2 & $-1,6$ & 175,2 & 193,5 & 18,3 & 1,9 \\
\hline Mljet & 46,4 & 47,5 & 1,1 & 29,4 & 28,2 & $-1,2$ & 191,8 & 253,7 & 61,9 & 1,4 \\
\hline Dugi otok & 48,7 & 52,2 & 3,5 & 33,3 & 35,1 & 1,8 & 277,6 & 409,2 & 131,6 & 1,0 \\
\hline Šolta & 48,4 & 52,1 & 3,7 & 30,1 & 31,6 & 1,5 & 249,7 & 423,6 & 173,9 & 0,9 \\
\hline
\end{tabular}

Izvor: Popis stanovništva, kućanstava i stanova 2001., Stanovništvo prema spolu i starosti, po naseljima, Državni zavod za statistiku, Zagreb, 2001., http://www.dzs.hr/Hro/censuses/ Census2001/Popis/H01_01_01/H01_01_01.html; Popis stanovništva, kućanstava i stanova 2011., Stanovništvo prema starosti i spolu po naseljima, Državni zavod za statistiku, Zagreb, 2011., http://www.dzs.hr/Hrv/censuses/census2011/results/htm/H01_01_01/H01_01_01.html.

Još jedan dokaz o »neuobičajenim « migracijama starije populacije leži u činjenici da su premošteni otoci, koji imaju najpovoljnije pokazatelje općega kretanja stanovništva, imali najveći porast prosječne dobi populacije od čak 3,2 godine. Tome su ponajviše pridonijeli otoci Vir i Čiovo (jedini kategorizirani tipom »ekspanzija imigracijom«), koji su u analiziranom razdoblju 
prosječno ostarjeli za 5,6 i 3,9 godina. Analiza koeficijenata starosti uglavnom ide u prilog do sada iznesenim zaključcima. Možda bi ipak trebalo naglasiti svojevrsnu anomaliju koja se ogleda u činjenici da je jedina otočna skupina kojoj se $\mathrm{u}$ analiziranom razdoblju smanjio koeficijent starosti skupina malih otoka. Do toga je došlo zbog izrazito visoke stope smrtnosti $(25,5 \%)$, odnosno umiranja četvrtine populacije $\left(\mathrm{M}=1181 ; \mathrm{P}_{2001}=4665\right)$ popisane 2001., od kojih je većina bila starije životne dobi. Njih je imigracijom djelomično zamijenila nešto mlađa populacija koja još nije napunila 65 godina te se tako snizila vrijednost koeficijenta starosti. Dakako, utjecaj rađanja na malim otocima nije bio bitan, što se jasno vidi iz velikog porasta indeksa starosti. Upravo nam indeks starosti stanovništva hrvatskih otoka još jednom otkriva ozbiljnost demografskog stanja na njima. Naime samo u jednom desetljeću na hrvatskom se otočju omjer starog i mladog stanovništva povećao za trećinu u korist stare populacije. Na početku analiziranog razdoblja 2001. na deset mladih (do petnaest godina starosti) dolazilo je trinaest starih stanovnika (65 godina i više), a 2011. na deset mladih dolazi sedamnaest starih. Porast indeksa starosti zabilježen je na svim otočnim skupina, i to u iznosima koji su za oko trećinu viši nego 2001. (blagi otklon imaju južnodalmatinski otoci, kod kojih je indeks starosti porastao za »tek« $18 \%$, i premošteni otoci s porastom od $42 \%$ ). Brzina rasta indeksa starosti, a posebice njegove dosegnute vrijednosti dovode u pitanje ne samo biodinamički potencijal otočne populacije već i bilo kakav razvojni potencijal tog dijela Republike Hrvatske.

Za kraj analize dobnog sastava stanovništva hrvatskog otočja izabran je indeks vitalnosti kao složeni pokazatelj stupnja ostarjelosti i vitalnosti populacije. Njegove vrijednosti ni na jednom otoku ili otočnoj skupini nisu dosegnule vrijednost 10, što jasno pokazuje visoki stupanj ostarjelosti analizirane populacije. Budući da je indeks vitalnosti sintetični pokazatelj koji sadržava pokazatelje prirodnoga kretanja i dobnog sastava stanovništva, on nam je i svojevrstan indikator vitalnosti prostora za koji se izračunava. U našem slučaju, ma koliko bio nizak indeks vitalnosti, može se zaključiti da postoji svojevrsna pozitivna korelacija između indeksa i veličine otoka. I kod tog su se indikatora kao najvitalniji izdvojili premošteni otoci Vir i Čiovo, dok u vitalnosti ozbiljno posustaju mali hrvatski otoci. 


\section{ZAKLJUČAK}

Ova kraća analiza demografskog stanja i promjena na hrvatskim otocima na početku 21. stoljeća pokazala je da »fiktivno stanovništvo « predstavlja ozbiljan problem demografskim analitičarima, ali bi moglo biti i prepreka realizaciji razvojnih planova koji bi se na njima temeljili. Ono otočnoj populaciji daje kratkotrajan pozitivan učinak koji se očituje u statističkom povećanju broja stanovnika, a dugotrajno zamagljuje njezino stvarno demografsko stanje. Riječ je naime o formalnome, a ne stvarnome povećanju broja stanovnika. Budući da je otok jasno definirani prostor (dio kopna sa svih strana omeđen morem) i ima ograničene resurse, jasno je da se na njemu ne može beskrajno graditi i beskrajno fiktivno prijavljivati. Zato je legitimno upitati hoće li uskoro doći do apsurda da mali otoci imaju sto posto »fiktivnog stanovništva«. Kako se u tom slučaju postaviti kao demografski analitičar, a kako kao planer? Zapravo, ako pretpostavimo da s padom živosti otočnog stanovništva raste udio "fiktivnog stanovništva«, relativno lako možemo detektirati otoke koji bi mogli u potpunosti biti fiktivno naseljeni. Tome nam može pomoći odgovor na pitanje postavljeno na kraju uvodnog dijela: ponestaje li životne snage na hrvatskim otocima? Provedena analiza na razini ukupnog stanovništva hrvatskih otoka daje oprečne odgovore: uočene naznake pozitivnoga linearnog trenda prirodnoga kretanja upućuju na negativan, dok svi pokazatelji dobnog sastava stanovništva upućuju na pozitivan odgovor. Zato analiza na razini i skupina i pojedinačnih otoka lakše vodi do odgovora na postavljeno pitanje. Može se ustvrditi da je populacijska veličina otoka u pozitivnoj korelaciji s vitalnošću; premoštenost otoka jača životnu snagu njegovih stanovnika; malim otocima i onima udaljenim od kopna ponestalo je životne snage, a svi ostali otoci na putu su da je izgube.

\section{LITERATURA}

Duplančić, T., Ujević, T. i Čala, M. (2004). Coastline lenghts and areas of islands in the Croatian part of the Adriatic Sea determined from the topographic maps at the scale of 1:25000, Geoadria, 9 (1): 5-32.

Faričić, J., Graovac, V. i Čuka, A. (2010). Mali hrvatski otoci - radno-rezidencijalni prostor i/ili prostor odmora i rekreacije, Geoadria, 15(1): 145-185.

Friganović, M. A. (2001). Demografska problematika hrvatskih otoka, Sociologija sela, 39 (1/4): 37-59.

Friganović, M. i Pavić, P. (1973). Uzroci i posljedice demografskih promjena u SR Hrvatskoj 1961-1971. Zagreb: IDIS. 
Lajić, I. (1992). Stanovništvo dalmatinskih otoka. Zagreb: Consilium - Institut za migracije i narodnosti.

Lajić, I. (1997). Suvremena demografska problematika jadranskih otoka, u: N. Starc, M. Kaštelan-Macan i S. Ćurlin (ur.). Nacionalni program razvitka otoka. Zagreb: Ministarstvo razvitka i obnove.

Lajić, I. (2006). Kvarnerski otoci - demografski razvoj i povijesne mijene. Zagreb: Institut za migracije i narodnosti.

Lajić, I. i Mišetić, R. (2006). Otočni logaritam: aktualno stanje i suvremeni demografski procesi na jadranskim otocima. Zagreb: Institut za migracije i narodnosti - Ministarstvo mora, turizma, prometa i razvitka.

Magaš, D. (2008). Geografske posebnosti razvitka malih hrvatskih otoka, u: J. Faričić (ur.). Otok Rava. Zadar: Sveučilište u Zadru, 19-42.

Miletić, G. M. (2006). Stavovi lokalne javnosti o nekim socijalno-ekologijskim posljedicama izgradnje stanova za odmor na otoku Viru, Društvena istraživanja, 15 (1-2): 43-60.

Nejašmić, I. (1992). Promjene u dobno-spolnom sastavu stanovništva istočnojadranskog otočja (1953-1991), Acta Geographica Croatica, 27: 15-34.

Nejašmić, I. (2000). Prirodno kretanje stanovništva hrvatskog otočja (1991-1997), u: D. Pejnović (ur.): Zbornik radova 2. hrvatskog geografskog kongresa. Zagreb: Hrvatsko geografsko društvo, 263-272.

Nejašmić, I. (2005). Demogeografija - stanovništvo u prostornim odnosima i procesima. Zagreb: Školska knjiga.

Smoljanović, M., Smoljanović, A. i Nejašmić, I. (1999). Stanovništvo hrvatskih otoka. Split: Zavod za javno zdravstvo Splitsko-dalmatinske županije.

\section{IZVORI}

Popis stanovništva, domaćinstava $i$ stanova 1981., Stanovništvo po naseljima, općinama $i$ zajednicama općina, Dokumentacija 553, Republički zavod za statistiku, Zagreb, 1984.

Popis stanovništva, domaćinstava, stanova i poljoprivrednih gospodarstava, 31. 3. 1991. Stanovništvo u zemlji i u inozemstou po naseljima, Dokumentacija 911, Državni zavod za statistiku, Zagreb, 1996.

Popis stanovništva, kućanstava $i$ stanova 2001., Stanovništvo prema spolu i starosti, po naseljima, DZS, Zagreb, 2001., http://www.dzs.hr/Hrv/censuses/Census2001/Popis/ H01_01_01/H01_01_01.html.

Popis stanovništva, kućanstava i stanova 2001., Stanovi prema načinu korištenja, po naseljima, CD-ROM, Državni zavod za statistiku, Zagreb, 2004.

Popis stanovništva, kućanstava i stanova 2011., Prvi rezultati, Državni zavod za statistiku, Zagreb, 2011., http://www.dzs.hr/Hrv/censuses/census2011/firstres/htm/h11_ RH.html.

Popis stanovništva, kućanstava $i$ stanova 2011., Stanovništvo prema starosti $i$ spolu po naseljima, Državni zavod za statistiku, Zagreb, 2013, http://www.dzs.hr/Hrv/censuses/ census2011/results/htm/H01_01_01/H01_01_01.html.

Prirodno kretanje stanovništva Republike Hrvatske, po naseljima, za godišta od 2001. do 2011., tablogrami, Državni zavod za statistiku, Zagreb. 


\title{
Demographic Changes on Croatian Islands at the Beginning of the $21^{\text {st }}$ Century
}

\author{
Ivan Lajić, Roko Mišetić
}

\begin{abstract}
SUMMARY
Depopulation was the main feature of the demographic development of Croatian islands during a large part of the $20^{\text {th }}$ century. It started in 1921 and ended in the last decade of the century according to the official statistical indicators. It was caused by a long-term emigration from the islands, arising both from economic (agrarian overpopulation, land industrialisation, de-agrarisation, the crises of certain agricultural activities, monoculture on some of the islands, etc.) and political reasons (political emigration, Italian optants). Depopulation due to emigration was crucial in creating total depopulation up to the 1960s, and after that period it was joined by natural depopulation as well, leading many island communities to a state of extreme depopulation - extinction. But since the 1991 Census, the general population change on Croatian islands has got a positive sign. However, the conclusion that population revitalisation occurred on Croatian islands was soon denied by a series of facts. As the law, popularly called "the law on vacation homes", has been applied since 1993, a large number of second homes owners opted for this location as the predominant place of residence, although they do not reside there for the most part of the year, thus creating a significant contingent of "fictitious population". Another theory which denies that our islands are experiencing demographic upswing and revitalisation rests on the fact that far and away the highest rates of population growth have been recorded on the bridged islands. We believe that these islands (also characterized by the highest proportion of second homes in the total number of objects) do not share the fate of islandness (insularity) as the other "real islands" do, owing to their solid connection to the mainland so that, in fact, they are no longer isolated. If we exclude the population trends of this group of islands from the total population change of the entire archipelago, we can affirm that even if "fictitious population" is accepted as a statistical reality, the population of our islands stagnated in the previous period.
\end{abstract}

KEY WORDS: Croatian islands, depopulation, population age structure, vitality, "fictitious population" 